\title{
Clusterin deficiency induces lipid accumulation and tissue damage in kidney
}

\author{
Jung-Yoon Heo,,2, Ji-Eun Kim,2, Yongwook Dan3, Yong-Woon Kim, Jong-Yeon Kim1, Kyu Hyang Cho4, \\ Young Kyung Bae ${ }^{5}$, Seung-Soon Im6, Kwang-Hyeon Liü, In-Hwan Song ${ }^{8}$, Jae-Ryong Kim ${ }^{2,9}$, In-Kyu Lee ${ }^{10}$ and \\ So-Young Park ${ }^{1,2}$
}

'Department of Physiology, College of Medicine, Yeungnam University, Daegu, Korea

${ }^{2}$ Smart-Aging Convergence Research Center, College of Medicine, Yeungnam University, Daegu, Korea

${ }^{3}$ Weinberg College, Northwestern University, Evanston, Illinois, USA

${ }^{4}$ Department of Internal Medicine, College of Medicine, Yeungnam University, Daegu, Korea

5Department of Pathology, College of Medicine, Yeungnam University, Daegu, Korea

${ }^{6}$ Department of Physiology, Keimyung University School of Medicine, Daegu, Korea

${ }^{7}$ College of Pharmacy and Research Institute of Pharmaceutical Sciences, Kyungpook National University, Daegu, Korea

${ }^{8}$ Department of Anatomy, College of Medicine, Yeungnam University, Daegu, Korea

9Department of Biochemistry and Molecular Biology, College of Medicine, Yeungnam University, Daegu, Korea

${ }^{10}$ Department of Internal Medicine, School of Medicine, Kyungpook National University, Daegu, Korea

Correspondence should be addressed to S-Y Park: sypark@med.yu.ac.kr

\section{Abstract}

Clusterin is a secretory glycoprotein that is involved in multiple physiopathological processes, including lipid metabolism. Previous studies have shown that clusterin prevents hepatic lipid accumulation via suppression of sterol regulatory elementbinding protein (SREBP) 1. In this study, we examined the role of clusterin in renal lipid accumulation in clusterin-knockout mice and NRK52e tubular epithelial cells. Clusterin deficiency increased the expression of SREBP1 and its target genes and decreased malonyl-CoA decarboxylase protein levels in the kidney. Expression of the endocytic receptor, megalin, and scavenger receptor class A was increased in clusterindeficient mice. Functional analysis of lipid metabolism also revealed that lipid uptake and triglyceride synthesis were increased and fatty acid oxidation was reduced, leading to increased lipid accumulation in clusterin-deficient mice. These phenomena were accompanied by mesangial expansion, fibrosis and increased urinary proteinto-creatinine ratio. High-fat feeding aggravated these clusterin deficiency-induced pathological changes. Clusterin knockdown in NRK52e cells increased lipogenic gene expression and lipid levels, whereas overexpression of clusterin by treatment with adenovirus or recombinant clusterin protein suppressed lipogenic gene expression and lipid levels. Transforming growth factor-beta 1 (TGFB1) expression increased in the kidney of clusterin-deficient mice and suppression of TGFB1 in NRK52e cells suppressed lipid accumulation. These results suggest that clusterin deficiency induces renal lipid accumulation by dysregulating the expression of lipid metabolism-related factors and TGFB1, thereby leading to chronic kidney disease. Hence, clusterin may serve as a therapeutic target for lipid-induced chronic kidney disease.

\author{
Key Words \\ - clusterin \\ - lipid metabolism \\ - chronic kidney disease \\ - SREBP \\ - TGFB1
}

Journal of Endocrinology (2018) 237, 175-191 


\section{Introduction}

Obesity is a major risk factor for metabolic diseases and is directly associated with diabetes, hypertension and hyperlipidemia (Mokdad et al. 2003). Recently, obesity is being increasingly recognized as a major and independent risk factor for the development of chronic kidney disease (Laville 2011, Odagiri et al. 2014). One of the proposed mechanisms for obesity-induced chronic kidney disease is lipid accumulation induced by abnormal lipid metabolism, reduced utilization of lipid and/or increased lipid synthesis (Bobulescu 2010, Mount et al. 2015).

Lipid accumulation results in increased intracellular free fatty acids, leading to a build-up of lipotoxic metabolites, such as fatty acyl-CoA, ceramide and diacylglycerol (Bobulescu 2010). Proposed mechanisms for tissue injury by lipotoxicity include reactive oxygen species generation, inflammation, apoptosis and disruption of signaling pathways (Bobulescu 2010). Structural changes in the kidney of obese patients include mesangial expansion, glomerulosclerosis, tubular atrophy and interstitial fibrosis (Kambham et al. 2001). These structural changes are followed by a progressive decrease in renal function, including increased proteinuria and decreased glomerular filtration rate, leading to end-stage renal diseases (Wahba \& Mak 2007, Kiortsis \& Christou 2012). Chronic high-fat feeding induces obesity in mice, and causes pathological changes in the kidney, similar to obesity-induced renal disease in humans (Szeto et al. 2016).

Sterol regulatory element-binding proteins (SREBPs) are transcription factors that induce lipogenic gene expression. Among the three isoforms of SREBPs, SREBP1a and SREBP1c are produced from a single gene with a difference in the first exon, and SREBP2 is encoded by a separate gene (Hua et al. 1995, Eberle et al. 2004). SREBP1a and SREBP1c are more active in driving the transcription of genes involved in fatty acid synthesis, including fatty acid synthase (FAS), acetyl-CoA carboxylase (ACC) and stearoyl-CoA desaturase (SCD) (Nohturfft et al. 1999, Oh et al. 2003, Gosmain et al. 2005), whereas SREBP2 is more active in driving genes involved in cholesterol metabolism, including 3-hydroxyl-3methylglutaryl coenzyme A reductase (HMGCR) and low-density lipoprotein receptor (LDLR), leading to increased cholesterol accumulation (Shimano et al. 1997, Nohturfft et al. 1999). The expression of SREBP and its target gene is increased in mouse and human obesity (Jiang et al. 2005a,b, Pettinelli et al. 2009). Increased expression of SREBP1 induces lipid accumulation, fibrosis and kidney dysfunction (Sun et al. 2002), whereas deficiency of SREBP1 prevents lipid accumulation and fibrosis (Jiang et al. 2005b, Ishigaki et al. 2007).

Fatty acid oxidation is one of the important energyproducing pathways in the kidney, particularly in the proximal tubules (Mount et al.2015). Fatty acids are usually bound to albumin in the plasma, and albumin-bound fatty acids filtered through glomerular capillaries are taken up through the endocytic receptor, megalin, located on the apical side of cells in proximal tubules (Bobulescu 2010, Mount et al. 2015). Unbound fatty acids in circulation are usually taken up by cells through transporters such as CD36 and fatty acid-binding proteins (Bobulescu 2010, Mount et al. 2015). Impaired fatty acid oxidation and reduced expression of genes related to fatty acidbeta oxidation including carnitine palmitoyltransferase 1 (CPT1) and acyl-coenzyme A oxidase (ACO) are associated with increased lipid accumulation and fibrosis in the kidney (Kang et al. 2015). Malonyl coenzyme A (CoA) decarboxylase (MCD) catalyzes the conversion of malonyl-CoA into acetyl-CoA, and inhibition of MCD increases malonyl-CoA levels, leading to reduced fatty acid oxidation by suppression of CPT1 activity in the heart, liver, skeletal muscle and kidney (Lloyd et al. 1986, Stanley et al. 2005).

Clusterin is an $80-\mathrm{kDa}$ heterodimeric glycoprotein composed of alpha and beta chains linked by disulfide bonds (Rosenberg \& Silkensen 1995). Clusterin is expressed in a wide array of mammalian tissues and has been functionally implicated in a variety of physiological and pathological processes, including lipid metabolism (Rosenberg \& Silkensen 1995). Clusterin is a component of high-density lipoprotein (HDL) (Jenne et al. 1991) and suppresses SREBP1c expression in the liver (Seo et al. 2013). Furthermore, clusterin has preventive effects on atherosclerosis, diabetes and hepatic steatosis (Hamada et al. 2011, Seo et al. 2013, Kwon et al. 2014).

Clusterin is closely associated with renal diseases and its expression increases in polycystic kidney disease (Dvergsten et al. 1994), ischemic renal tissues (Zhou et al. 2010) and lupus-like nephritis (Moll et al. 1998) in humans and mice. Moreover, clusterin attenuates renal fibrosis (Jung et al. 2012), ischemic renal tissue injury (Zhou et al. 2010) and a progressive glomerulopathy of aging (Rosenberg et al. 2002). However, the role of clusterin in lipid accumulation and obesity-induced tissue damage in the kidney is unknown. To determine the role of clusterin in renal lipid metabolism, we fed a control diet or a high-fat diet to clusterin-knockout (KO) or wild-type mice and analyzed the molecular and functional aspects 
of lipid metabolism as well as pathological changes in the kidney. We also used NRK52e renal tubular epithelial cells to explore the role of clusterin in lipid metabolism in vitro.

\section{Materials and methods}

\section{Animals}

Male C57BL/6 wild-type and clusterin KO mice (Kwon et al. 2014) were housed in the animal room of Yeungnam University College of Medicine with a 12-h light-12-h darkness cycle. Mice aged 8 weeks old were fed for 12 weeks with either control diet (\#12450B; 10\% of total calories from fat and $20 \%$ protein) or high-fat diet (\#12492; 60\% fat and 20\% protein) from Research Diets (New Brunswick, NJ, USA) unless stated otherwise. For the fasting-refeeding study, all mice were fed a chow diet. Mice in the fasting group were fasted for $24 \mathrm{~h}$, and mice in the refeeding group were refed for $12 \mathrm{~h}$ after $24 \mathrm{~h}$ of fasting. The mice were anesthetized via an intraperitoneal injection of $250 \mathrm{mg} / \mathrm{kg}$ avertin (a mixture of 2,2,2-tribromoethanol and tert-amyl alcohol). All animal experiments were conducted following the institutional guidelines for laboratory animals and approved by the Ethics Committee of Yeungnam University (YUMC-AEC2013-018).

\section{Plasma and tissue lipids analysis}

Plasma levels of triglycerides (Sigma-Aldrich) and total and HDL cholesterol (Asan Pharmaceutical, Seoul, South Korea) levels were measured via an enzymatic colorimetric method. For the renal lipid assay, lipid was extracted by a modified version of Folch's method as previously described (Kwon et al. 2014).

\section{Urinary protein and creatinine assays}

To assess protein levels in urine, urine samples were precipitated with an equal volume of $30 \%$ trichloroacetic acid, dissolved in $1 \mathrm{M} \mathrm{NaOH}$, and then assayed using the Bradford protein assay (Bio-Rad). Creatinine levels were measured using the Creatinine Colorimetric/Fluorometric Assay Kit according to manufacturer's instruction (Biovision, Milpitas, CA, USA).

\section{Direct infusion-mass spectrometry analysis}

For the preparation of samples, total lipids from the kidney samples were extracted using a modified Masson method
(Masson et al. 2010). Kidney lipid profiling was performed on an LTQ XL mass spectrometer (Thermo Fischer Scientific) equipped with an automated nanospray source (TriVersa Nanomate; Advion Biosciences, Ithaca, NY, USA) using nanoelectrospray chips. MS data obtained from mass spectrometer were aligned using Genedata Expressionist MSX software (Genedata AG, Basel, Switzerland) directly from raw files to obtain a data matrix containing variables with $\mathrm{m} / \mathrm{z}$ values and peak intensities for multivariate analysis (Shon et al. 2015, Wu et al. 2016). MS/MS spectra were analyzed for the identification of lipid species using LipidBlast (Kind et al. 2013) and an in-house library.

\section{Lipid metabolism analysis}

Lipid uptake and triglyceride synthesis in vivo: Mice were administered with $300 \mu \mathrm{L}$ of vegetable oil containing $4 \mu \mathrm{Ci} \quad\left[{ }^{14} \mathrm{C}\right]$ palmitate (PerkinElmer) or $4 \mu \mathrm{Ci} \quad\left[{ }^{3} \mathrm{H}\right]$ cholesterol (PerkinElmer) by oral gavage. After $3 \mathrm{~h}$, mice were anesthetized with avertin, and kidney and liver were taken for analysis. For 24-h palmitate uptake, mice were killed $24 \mathrm{~h}$ after oral gavage of $4 \mu \mathrm{Ci}\left[{ }^{14} \mathrm{C}\right]$ palmitate. Tissue samples were solubilized using an NCS-II tissue solubilizer (Amersham Biosciences), and tissue solutions were acidified with glacial acetic acid. After centrifugation, $500 \mu \mathrm{L}$ of supernatant was added to $5 \mathrm{~mL}$ of BCS-NA counting scintillation cocktail (Amersham Biosciences), and radioactivity was analyzed using a liquid scintillation counter (Tri-Carb 4910; PerkinElmer). For triglyceride synthesis, triglyceride was separated from neutral lipid using silica Sep-Pak columns according to a previous study (Hamilton \& Comai 1988), and radioactivity in the triglyceride portion was then analyzed. Briefly, kidneys from the 24-h palmitate uptake experiment were homogenized in a chloroform methanol mixture, and the chloroform layer was evaporated. The samples were then dissolved in 200:3 hexane/methyl tert-butyl ether (MTBE) solution and applied to a Sep-Pak column (WAT020520, Waters, Milford, MA, USA). Triglycerides were eluted using a 96:4 hexane/MTBE mixture.

Fatty acid oxidation in vitro: Fatty acid oxidation rate was measured in homogenized kidney tissues as described previously (Kim et al. 2000). Briefly, $100 \mathrm{mg}$ of kidney sample was homogenized in buffer containing $250 \mathrm{mM}$ sucrose, $1 \mathrm{mM}$ EDTA and $10 \mathrm{mM}$ Tris- $\mathrm{HCl}$ (pH 7.4) using a motor-driven Teflon pestle. Protein content in the homogenate was measured for standardization. Fatty acid oxidation was measured using $\left[{ }^{14} \mathrm{C}\right]$ palmitate by collecting and counting the ${ }^{14} \mathrm{C}$ in the acid-soluble metabolite fraction and $\mathrm{CO}_{2}$ fraction. 


\section{Histological analysis}

The kidney samples were fixed in 4\% paraformaldehyde, embedded in paraffin and then cut into $4-\mu \mathrm{m}$ sections. To evaluate the renal structural changes, periodic acid-Schiff (PAS) and Masson trichrome staining were performed. The digital images were captured using ProgRes C14 plus microscope camera (Jenoptik AG, Jena, Germany), and ten glomeruli were selected for morphological analysis (ProgRes Capture Pro V 2.8.8; Jenoptik AG). From each slide, the extent of increase in the mesangial matrix was determined by assessing the PAS-positive area, and renal fibrosis was assessed by trichrome staining. For immunohistochemical staining of lysosomal-associated membrane glycoprotein 1 (LAMP1), 4- $\mu \mathrm{m}$ thick tissue sections were mounted on poly-L-lysine-coated slides. Endogenous peroxidase activity was inactivated by incubating the sections with $4 \% \mathrm{H}_{2} \mathrm{O}_{2}$ for $5 \mathrm{~min}$. After rinsing the sections in phosphate buffered saline, the tissue sections were incubated with primary antibody (1:200, polyclonal; Abcam, Cambridge, UK) for $30 \mathrm{~min}$ at room temperature. Visualization of positive staining was achieved using a DAKO EnVision Plus horseradish peroxidase-labeled polymer detection kit (DAKO) according to the manufacturer's instructions.

\section{Electron microscopy}

The kidney samples were cut into small blocks $\left(1 \mathrm{~mm}^{3}\right)$ and fixed overnight with $2.5 \%$ glutaraldehyde (Polysciences, Warrington, PA, USA) in $0.1 \mathrm{M}$ phosphate buffer. After washing 3 times in $0.1 \mathrm{M}$ phosphate buffer, the tissues were post-fixed in $2 \% \mathrm{OsO}_{4}$ (Polysciences) for $90 \mathrm{~min}$ followed by three washes with phosphate buffer. The tissues were dehydrated using ethanol, gradually infiltrated with propyleneoxide, and then embedded in Epon polymer. Ultrathin sections $(70 \mathrm{~nm})$ were obtained with an Ultracut $\mathrm{S}$ microtome (Leica Microsystems). Tissues were stained with uranyl acetate-lead citrate and observed under an $\mathrm{H}-7000$ transmission electron microscope (Hitachi) at an accelerating voltage of $75 \mathrm{kV}$. All lysosomal areas were measured and summed in a captured image $(\times 2500)$. Five mitochondria were randomly selected in the captured image $(\times 15000)$ and the mitochondrial areas were averaged.

\section{Cell culture and treatment with small interfering RNA, adenovirus or recombinant protein}

Rat NRK52e cells purchased from American Type Culture Collection (Manassas, VA, USA) were cultured in
Dulbecco's modified Eagle's medium supplemented with $10 \%$ fetal bovine serum and 1\% penicillin/streptomycin (Sigma-Aldrich). Clusterin small interfering RNAs (siRNAs) and non-silencing control siRNAs were purchased from Invitrogen and used according to the manufacturer's instructions. Cells in each well of a 12-well plate were transfected with clusterin siRNA or control siRNA at $100 \mathrm{nM}$ using Lipofectamine 2000 transfection reagent (Invitrogen) for $4 \mathrm{~h}$. Knockdown efficiency of siRNA was confirmed by quantitative real-time polymerase chain reaction (qRT-PCR) and Western blot analyses (Supplementary Fig. 1A, see section on supplementary data given at the end of this article). Adenovirusesexpressing clusterin (Ad-CLUs) were generated as previously described (Kwon et al. 2014). The efficiency of adenoviral infection was assessed using a recombinant Ad-CLU fused with green fluorescent protein (GFP) and Western blot analysis (Supplementary Fig. 1B). Control adenoviruses-expressing GFP were prepared by the same method. Recombinant clusterin protein (\#2747-HS-050) was purchased from R\&D Systems, and cells were treated with $1 \mu \mathrm{g}$ of recombinant clusterin protein.

\section{Oil Red O staining}

To measure intracellular lipid accumulation, NRK52e cells were stained with Oil Red O dye (Sigma-Aldrich). Cells in a 24-well plate were washed and fixed with $10 \%$ formaldehyde followed by incubation with the Oil Red O working solution for $30 \mathrm{~min}$ at room temperature in the dark. Subsequently, the cells were washed to remove any unbound Oil Red $\mathrm{O}$ dye and then observed under the microscope. After drying, the bound Oil Red O dye was eluted by addition of isoproterenol. The absorbance was measured at $550 \mathrm{~nm}$ and normalized according to protein concentration.

\section{Nuclei isolation and Western blotting}

Tissue nuclei extraction and Western blotting were performed as previously described (Kim et al. 2017). Briefly, nuclei were isolated using the nuclear/Cytosol Fractionation Kit (BioVision) according to manufacturer's instructions. The protein fraction from whole cells was separated on sodium dodecyl sulfate-polyacrylamide gel electrophoresis, and then transferred to a $0.45-\mu \mathrm{m}$ polyvinylidene difluoride membrane (Millipore). After blocking the membrane with 5\% skim milk in Tris-buffered saline containing Tween-20 (TBST), the membrane was incubated overnight at $4^{\circ} \mathrm{C}$ with the 
following primary antibodies (diluted 1:1000): clusterin (\#SC-6419; Santa Cruz Biotechnology), CD36 (\#100011; Cayman Chemical), collagen 4 (SC-70246; Santa Cruz Biotechnology), CPT 1 (\#SC-393070; Santa Cruz Biotechnology), FAS (\#3180; Cell Signaling Technology, Danvers, MA, USA), glyceraldehyde-3-phosphate dehydrogenase (GAPDH; \#SC-25778; Santa Cruz Biotechnology), H3 (\#4499; Cell Signaling Technology), LAMP1 (\#ab24170; Abcam), MCD (\#ab95945; Abcam), megalin (\#ab129198, Abcam), SMAD2/3 (\#SC-133098; Santa Cruz Biotechnology), SREBP1 (\#SC-13551X; Santa Cruz Biotechnology) and transforming growth factor-beta (TGFB1; ab64715; Abcam). The membrane was washed in TBST and incubated with a secondary antibody for $1 \mathrm{~h}$ at room temperature. The blot was detected using a chemiluminescent reagent (Millipore).

\section{qRT-PCR}

RNA from the kidney sample was isolated using TRIzol reagent (Sigma-Aldrich) according to the manufacturer's instructions. A total amount of $1 \mu \mathrm{g}$ of RNA was reversetranscribed to cDNA using a reverse transcription kit (Applied Biosystems). Power SYBR Green PCR master mix (Applied Biosystems) was used for real-time PCR (RT-PCR) according to the manufacturer's instructions, using real-time 7500 software system (Applied Biosystems). Primers for mouse were based on NCBI's Nucleotide database and designed using the Primer Express program (Applied Biosystems). The primer sequences are shown in Supplementary Table 1.

\section{Statistical analysis}

SPSS, version 23 (SPSS) was used for statistical analysis. Data are expressed as the mean \pm standard error (s.e.). Differences between two groups were analyzed with unpaired Student's $t$-test. A two-way analysis of variance (ANOVA) was used to evaluate the interaction between independent variables, followed by Tukey post hoc test. A $P<0.05$ was considered to be statistically significant.

\section{Results}

\section{Clusterin deficiency alters the expression of lipid metabolism-related factors and cytokines}

To elucidate the pathophysiological factors that regulate clusterin expression in the kidney, we measured renal clusterin protein levels in wild-type mice under fastingrefeeding or following high-fat feeding for 12 weeks. Clusterin protein levels in the kidney were significantly decreased by refeeding compared with those of fasting (Fig. 1A). This result is consistent with previous studies in which plasma clusterin levels and hepatic expression of clusterin were reduced by feeding compared to fasting (Gil et al. 2013, Seo et al. 2013), suggesting the nutritional regulation of clusterin in the kidney. In contrast, the clusterin protein levels were increased in the kidney of high-fat-fed obese mice (Fig. 1B). Previously, we observed higher levels of clusterin in the plasma of high-fat dietinduced obese mice (Kwon et al. 2014). These results suggest the possible role of clusterin in obesity-related renal diseases.

To further examine the relationship between clusterin and obesity in the kidney, we measured the expression levels of genes and proteins involved in lipid metabolism in clusterin $\mathrm{KO}$ and wild-type mice fed a control diet. The mRNA levels of Cd36, Fabp1, Fabp3, Slc27a2 and Slc27a4, which are genes involved in fatty acid transportation, were not significantly different between wild-type and clusterin KO mice. The mRNA levels of Srebf1, Fasn and Acaca were increased in clusterin KO mice compared to wild-type mice, whereas the expression levels of fatty acidbeta-oxidation-related genes, Cpt1a, Acox 1 and Mlycd, were not significantly altered by clusterin deficiency (Fig. 1C). The mRNA levels of Srebp2 and Hmgcr were not different between the two groups. The gene expression levels of Sacra1were increased in clusterin KO mice, but the mRNA levels of $S c a r b 1$ were not different between the two groups (Fig. 1D). The mRNA levels of $I l 6$ and $I l 1 b$ were increased in clusterin KO mice (Fig. 1E). Accordingly, the protein levels of SREBP1and FAS were higher in clusterin KO mice than wild-type mice, whereas the protein levels of CD36 and CPT1 were similar between the two genotype groups. However, the protein levels of MCD were significantly reduced in clusterin $\mathrm{KO}$ mice although the mRNA levels of Mlycd were similar (Fig. 1F, G, H, I and J). These results suggest that clusterin deficiency dysregulates the expression of lipid metabolism-related factors and induces inflammation in the kidney.

\section{Clusterin deficiency induces lipid accumulation and fibrosis}

To examine the role of clusterin in renal function and lipid accumulation, we fed a control diet or a high-fat diet to wild-type and clusterin $\mathrm{KO}$ mice for 12 weeks, and then measured the renal lipid levels and protein-to- 
A
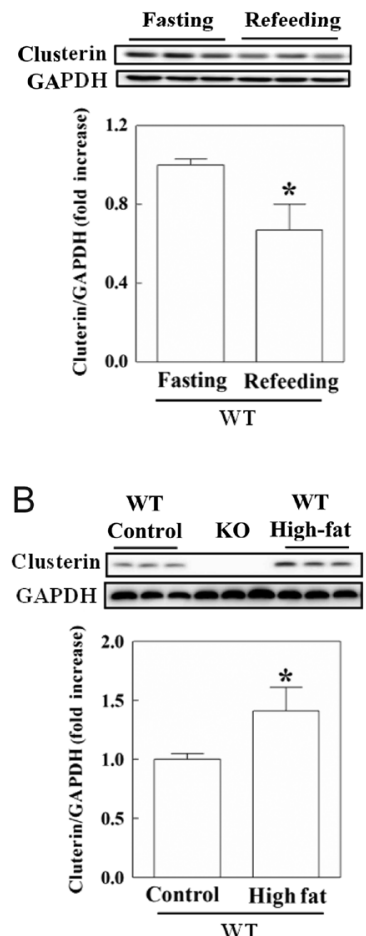

C

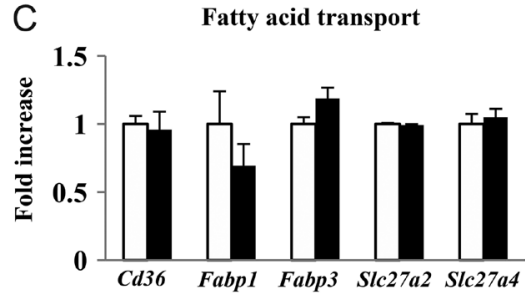

D

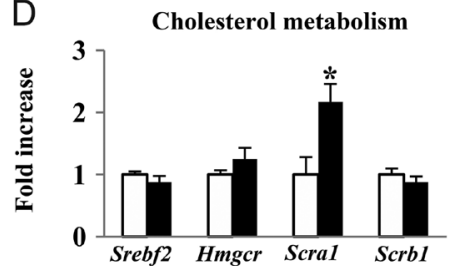

F

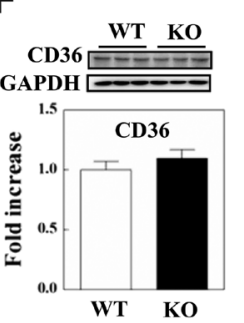

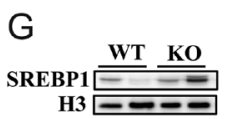

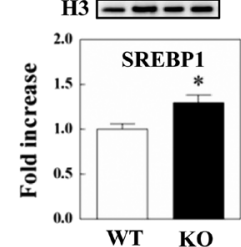

Fatty acid synthesis

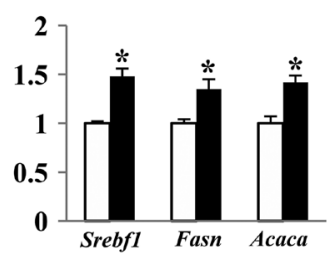

E Inflammatory cytokines

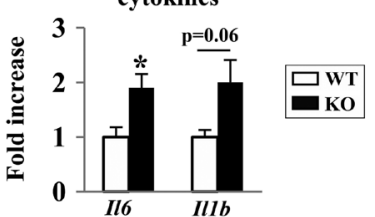

$\mathrm{H}$

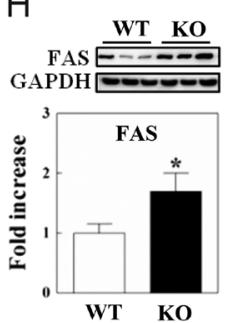

Fatty acid oxidation

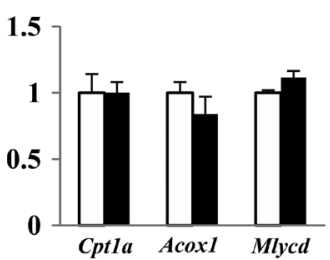

Figure 1

Renal expression of clusterin, lipid metabolism-related proteins and cytokines in clusterin KO and wild-type mice. Protein levels of clusterin during fasting-refeeding $(A)$ and 12 weeks of high-fat feeding $(B)$ in wild-type mice. Mice in the fasting group were fasted for $24 \mathrm{~h}$, and mice in refeeding group were refed for $12 \mathrm{~h}$ after $24 \mathrm{~h}$ of fasting. Gene expression of lipid metabolism-related proteins (C and D) and cytokines (E). Protein expression of lipid metabolism-related proteins (F, G, H, I and J). Gene and protein expression levels were measured by qRT-PCR and Western blotting, respectively. The results are presented as the mean \pm S.E. for $5-9$ experimental cases in each group. ${ }^{*} P<0.05$ vs fasting, control or wild type. CPT1, carnitine palmitoyltransferase 1; FAS, fatty acid synthase; KO, knockout; MCD, malonyl-CoA decarboxylase; SREBP1, sterol regulatory element-binding protein 1; WT, wild-type.

creatinine ratio. The body weight, fat mass and plasma levels of lipids were not different between the wild-type and clusterin $\mathrm{KO}$ mice in the control diet group. However, the high-fat diet increased the body weight and fat mass in mice of both genotypes (Table 1). The plasma levels of triglyceride and total cholesterol were also increased by the high-fat diet, but there was no significant difference between the two genotypes. The plasma levels of HDL were not significantly affected by clusterin deficiency or high-fat diet (Table 1). Renal triglyceride levels assessed by lipid extraction were significantly higher in high-fatfed clusterin KO mice compared with control diet-fed wild-type mice. High-fat diet did not significantly affect triglyceride levels in wild-type mice (Fig. 2A). Increased triglyceride levels in clusterin $\mathrm{KO}$ mice were also confirmed by direct infusion-mass spectrometry analysis (Table 2 ).

Table 1 Body weight, fat mass and plasma lipid levels in control diet- and high-fat diet-fed clusterin knockout and wild-type mice.

\begin{tabular}{|c|c|c|c|c|}
\hline \multirow[b]{2}{*}{ Group } & \multicolumn{2}{|c|}{ Control diet } & \multicolumn{2}{|c|}{ High-fat diet } \\
\hline & Wild-type & Clu KO & Wild-type & Clu KO \\
\hline Body weight (g) & $33.4 \pm 0.19$ & $33.7 \pm 0.14$ & $44.4 \pm 0.13^{*}$ & $44.2 \pm 0.12^{*}$ \\
\hline Fat mass (\% BW) & $1.7 \pm 0.04$ & $1.4 \pm 0.05$ & $2.6 \pm 0.05^{*}$ & $2.5 \pm 0.05^{*}$ \\
\hline Triglyceride (mM) & $0.4 \pm 0.04$ & $0.4 \pm 0.02$ & $0.7 \pm 0.06^{*}$ & $0.6 \pm 0.05^{*}$ \\
\hline Total cholesterol (mM) & $3.2 \pm 0.16$ & $3.5 \pm 0.15$ & $4.4 \pm 0.16^{*}$ & $4.5 \pm 0.18^{*}$ \\
\hline HDL cholesterol (mM) & $2.7 \pm 0.13$ & $2.5 \pm 0.09$ & $2.6 \pm 0.11$ & $2.8 \pm 0.06$ \\
\hline
\end{tabular}

Results are presented as mean \pm S.E. Experimental cases are 7-9 per group. ${ }^{*} P<0.05$ vs wild-type in control diet and ${ }^{\#} P<0.05$ vs Clu $\mathrm{KO}$ in control diet. Clu KO, clusterin knockout; HDL, high-density lipoprotein. 


\begin{tabular}{l|l|l|l|} 
Journal of & J-Y Heo et al. & $\begin{array}{l}\text { Role of clusterin in renal lipid } \\
\text { accumulation }\end{array}$ & $\mathbf{2 3 7 : 2}$ \\
Endocrinology & & $\mathbf{1 8 1}$
\end{tabular}

A
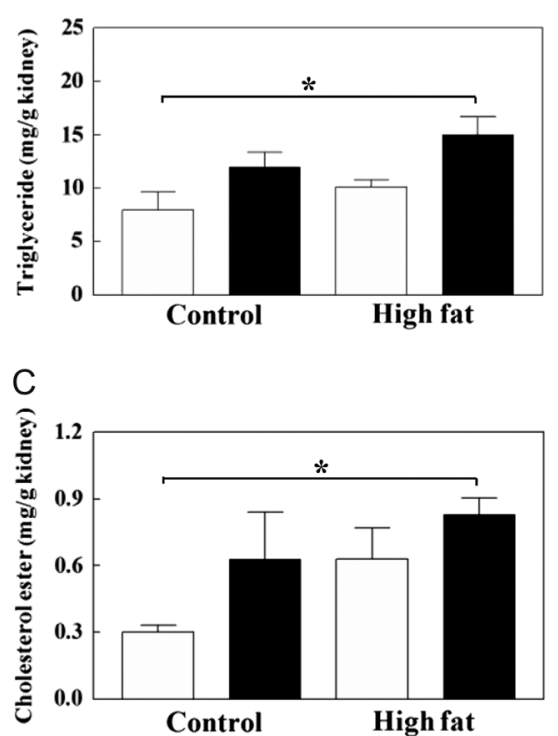

$\mathrm{B}$

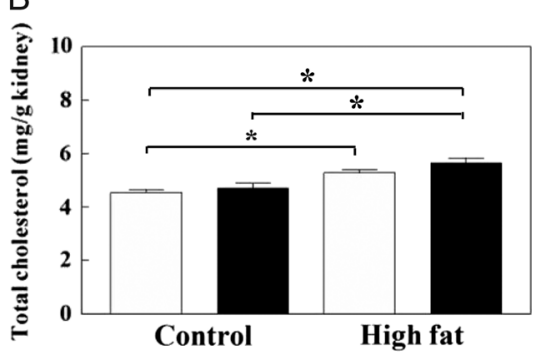

D

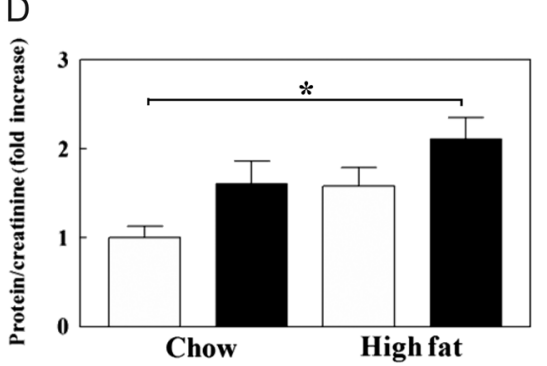

\section{Figure 2}

Renal lipid levels and urine protein-to-creatinine ratio in clusterin $\mathrm{KO}$ and wild-type mice. Renal lipids were extracted by a modified Folch's method, and triglyceride levels were measured by enzymatic colorimetric methods (A). Total cholesterol (B) and cholesterol ester levels (C) were measured by direct infusion mass spectrometry analysis. The urine protein-tocreatinine ratio was measured as described in the materials and methods section (D). The results are presented as the mean \pm S.E. for 5-9 experimental cases in each group. ${ }^{*} P<0.05$. KO, knockout; WT, wild type.
Tissue cholesterol levels were also assessed by direct infusion-mass spectrometry analysis. Total cholesterol levels were increased by high-fat diet both in wild-type and clusterin $\mathrm{KO}$ mice, and they were higher in highfat-fed clusterin $\mathrm{KO}$ mice than in high-fat-fed wild-type mice $(P=0.15)$. Like triglyceride, cholesterol ester levels in high-fat-fed clusterin KO mice were significantly higher than in control diet-fed wild-type mice (Fig. 2B and C). These results suggest that clusterin deficiency increases renal lipid levels without affecting obesity parameters. Urinary protein-to-creatinine ratio was higher in highfat-fed clusterin $\mathrm{KO}$ mice than in control diet-fed wild- type mice (Fig. 2D), suggesting that clusterin deficiency reduces renal function.

We next examined if clusterin deficiency induces tissue damage by assessing histological alterations and expression of extracellular matrix-related proteins. The mesangial matrix area was increased in clusterin KO mice compared to wild-type mice in the control diet group. A high-fat diet significantly increased the mesangial matrix area in both genotypes; however, the mesangial matrix area in KO mice was significantly higher than that in wild-type mice (Fig. 3A). Interstitial fibrosis in clusterin KO mice was higher than that in wild-type mice in the

Table 2 Quantitative fold changes in renal triglyceride levels in clusterin knockout mice.

\begin{tabular}{|c|c|c|}
\hline No. & $m / z$ & Adduct \\
\hline 1 & 792.6 & $\mathrm{M}+\mathrm{NH}_{4}$ \\
\hline 2 & 794.6 & $\mathrm{M}+\mathrm{NH}_{4}$ \\
\hline 3 & 796.6 & $\mathrm{M}+\mathrm{NH}_{4}$ \\
\hline 4 & 818.6 & $\mathrm{M}+\mathrm{NH}_{4}$ \\
\hline 5 & 820.6 & $\mathrm{M}+\mathrm{NH}_{4}$ \\
\hline 6 & 822.6 & $\mathrm{M}+\mathrm{NH}_{4}$ \\
\hline 7 & 824.6 & $\mathrm{M}+\mathrm{NH}_{4}$ \\
\hline 8 & 840.6 & $\mathrm{M}+\mathrm{NH}_{4}$ \\
\hline 9 & 842.6 & $\mathrm{M}+\mathrm{NH}_{4}$ \\
\hline 10 & 844.6 & $\mathrm{M}+\mathrm{NH}_{4}$ \\
\hline 11 & 846.6 & $\mathrm{M}+\mathrm{NH}_{4}$ \\
\hline 12 & 848.6 & $\mathrm{M}+\mathrm{NH}_{4}$ \\
\hline 13 & 850.6 & $\mathrm{M}+\mathrm{NH}_{4}$ \\
\hline 14 & 872.6 & $\mathrm{M}+\mathrm{NH}_{4}$ \\
\hline 15 & 874.6 & $\mathrm{M}+\mathrm{NH}_{4}$ \\
\hline 16 & 876.6 & $\mathrm{M}+\mathrm{NH}_{4}$ \\
\hline
\end{tabular}

\begin{tabular}{l} 
Metabolites \\
\hline TG 46:2 (14:0/16:1/16:1) \\
TG 46:1 (14:1/16:0/16:0) \\
TG 46:0 (14:0/16:0/16:0) \\
TG 48:3 (16:1/16:1/16:1) \\
TG 48:2 (16:0/16:1/16:1) \\
TG 48:1 (16:0/16:0/16:1) \\
TG 48:0 (16:0/16:0/16:0) \\
TG 50:6 (22:6/12:0/16:0) \\
TG 50:5 (16:1/18:3/16:1) \\
TG 50:4 (16:1/16:1/18:2) \\
TG 50:3 (18:2/16:1/16:0) \\
TG 50:2 (16:0/16:0/18:2) \\
TG 50:1 (16:0/16:0/18:1) \\
TG 52:4 (18:2/18:2/16:0) \\
TG 52:3 (18:2/16:0/18:1) \\
TG 52:2 (10:0/24:1/18:1) \\
\hline
\end{tabular}

\begin{tabular}{c}
\hline Fold change (vs WT) \\
\hline Clusterin knockout \\
\hline 0.23 \\
0.33 \\
0.11 \\
0.16 \\
0.20 \\
0.12 \\
0.07 \\
-0.28 \\
-0.06 \\
0.04 \\
0.17 \\
0.12 \\
0.07 \\
0.17 \\
0.22 \\
0.16 \\
\hline
\end{tabular}

$P$-value
0.42
0.06
0.06
0.40
0.008
0.21
0.43
0.15
0.54
0.32
0.05
0.28
0.40
0.09
0.07
0.18

WT, wild type. 


\begin{tabular}{l|l|l|l|}
$\begin{array}{l}\text { Journal of } \\
\text { Endocrinology }\end{array}$ & $\begin{array}{l}\text { Role of clusterin in renal lipid } \\
\text { accumulation }\end{array}$ & $\mathbf{2 3 7 : 2}$ \\
\hline
\end{tabular}
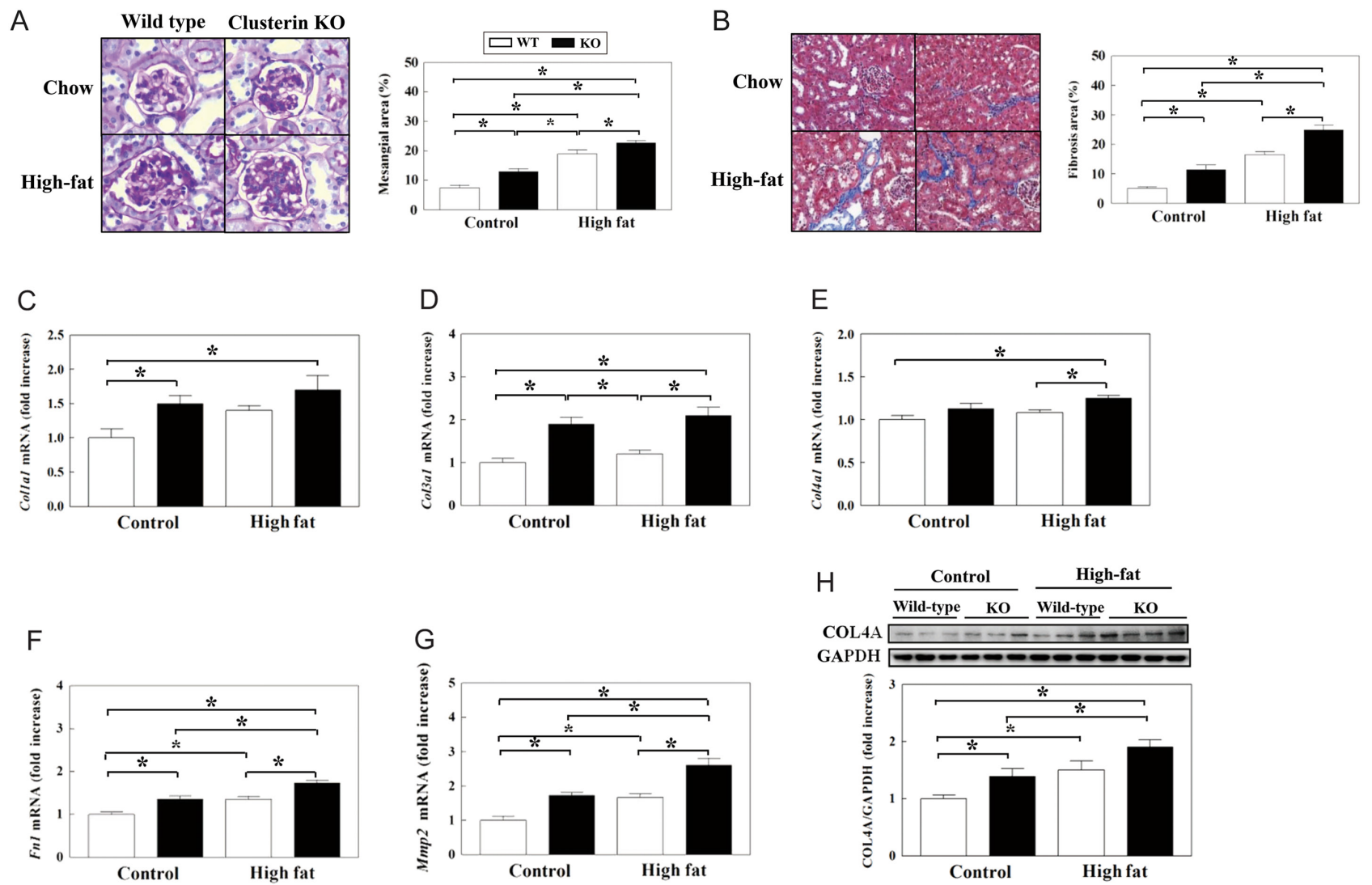

Figure 3

Histological analysis and expression of extracellular matrix-related factors in the kidney of clusterin KO and wild-type mice. Periodic acid-Schiff staining for the mesangial matrix area (A) and trichrome staining for interstitial fibrosis (B) were performed as described in the materials and methods section. Gene expression (C, D, E, F and G) was measured using qRT-PCR, and protein levels (H) were measured by Western blotting. The results are presented as the mean \pm S.E. for $7-9$ experimental cases in each group. ${ }^{*} P<0.05$. COL4A, collagen $4 \mathrm{~A} ; \mathrm{KO}$, knockout; $\mathrm{WT}$, wild type.

control diet group. The high-fat diet increased interstitial fibrosis in wild-type mice, and further increased it in clusterin KO mice (Fig. 3B). The mRNA levels of Col1a and Col3a1 were increased in clusterin $\mathrm{KO}$ mice as compared to wild-type mice (Fig. 3C and D). Col4a1 mRNA levels were similar between wild-type and clusterin $\mathrm{KO}$ mice in the control diet group. High-fat diet did not affect Col4a1 mRNA levels in wild-type mice. In contrast, Col4a1 mRNA levels in clusterin KO mice were significantly increased compared to wild-type mice following a high-fat diet (Fig. 3E). The mRNA levels of $F n 1$ and $M m p 2$ in clusterin KO mice were significantly higher than those in wildtype mice in the control diet group. The high-fat diet increased mRNA levels of $F n 1$ and Mmp2 in wild-type mice, and further increased their levels in clusterin $\mathrm{KO}$ mice (Fig. 3F and G). Accordingly, the COL4A protein levels were increased in clusterin $\mathrm{KO}$ mice compared to wild-type mice (Fig. 3H). These results suggest that clusterin deficiency induces renal fibrosis, which is further aggravated by high-fat feeding.
To further characterize the tissue damage in clusterindeficient mice, we performed electron microscopy analysis. Clusterin KO mice fed with a control diet showed an increase in the number and size of electron-dense lysosomes in the proximal tubules. The high-fat diet increased the number of lysosomes in both genotypes; however, clusterin $\mathrm{KO}$ mice contained higher numbers of lysosomes compared to wildtype mice (Fig. 4A). We also examined the mitochondrial size and morphology. The mitochondria were more deformed in shape in the high-fat-fed clusterin KO mice compared to the high-fat-fed wild-type mice. High-fat diet significantly increased mitochondrial size in clusterin $\mathrm{KO}$ mice, whereas it did not significantly affect the mitochondrial size in wildtype mice (Fig. 4B). To confirm the increase in the number of lysosomes in clusterin-deficient mice, we performed immunohistochemistry for LAMP1, a lysosomal marker. LAMP 1 staining was weakly positive in the luminal side of proximal tubules and in the epithelial cells of Bowman's capsule in the control diet-fed wild-type mice. LAMP1 staining in the luminal side of the proximal tubules was 
A
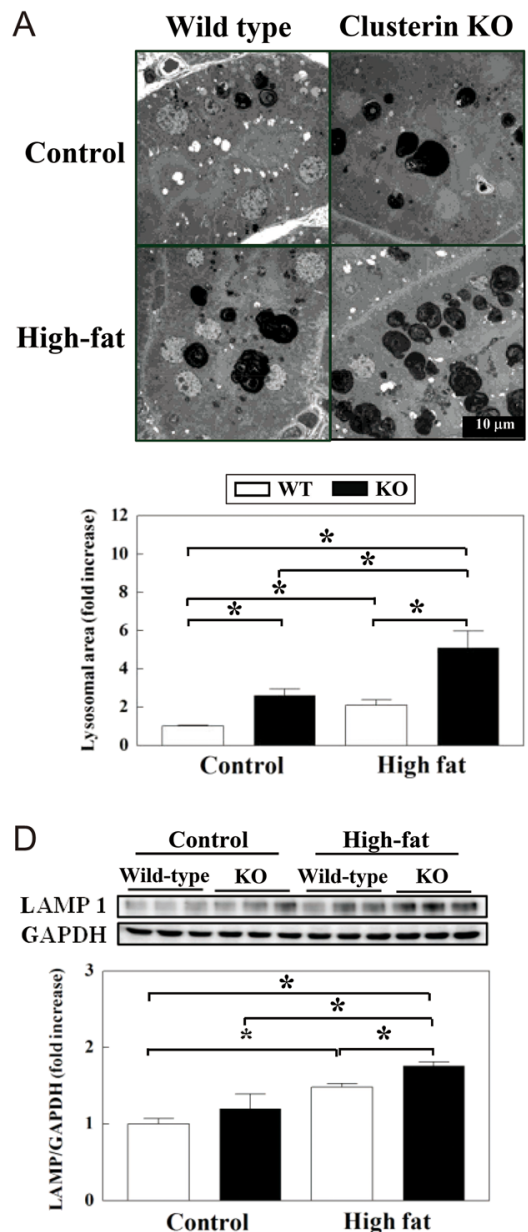

B

Wild type Clusterin KO
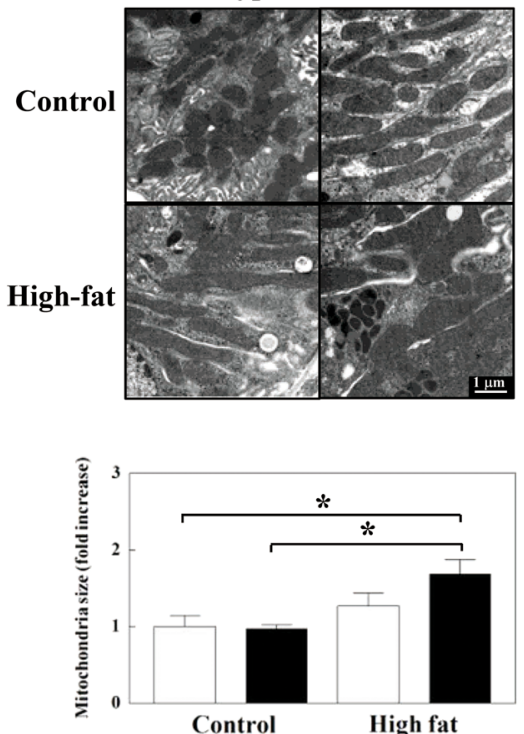

E
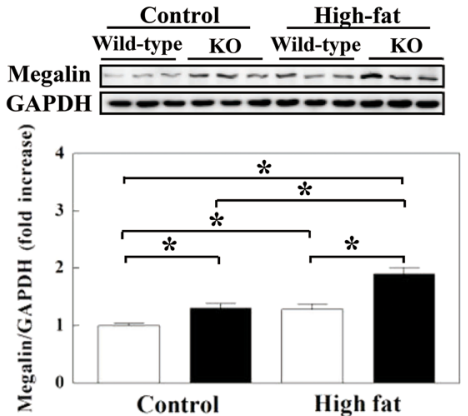

C
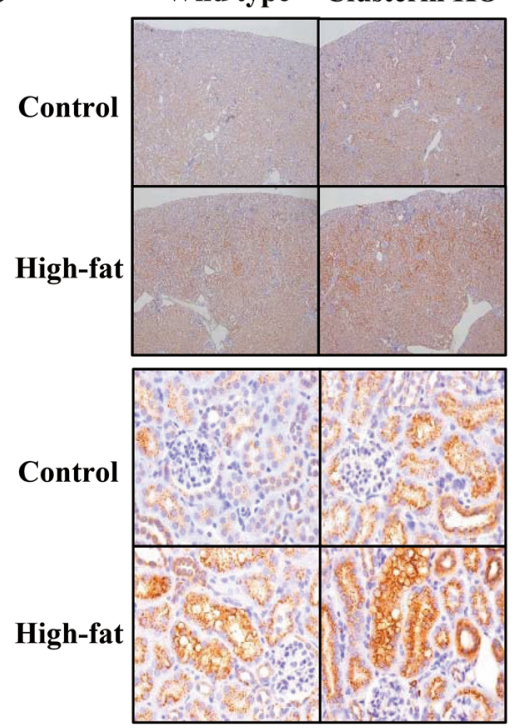

Figure 4

Electron microscopic analysis and protein levels of LAMP1 and megalin in the kidney of clusterin KO and wild-type mice. The proximal tubule under electron microscopy showed an increased number of electron-dense lysosomes in clusterin KO mice compared to wild-type mice in both diet groups (2500x, A). The mitochondria in high-fat diet-fed clusterin KO mice showed a larger and irregular shape (15,000x, B). Immunohistochemical staining of LAMP1 $(40 x$ and 400x, C). Protein levels of LAMP1 and megalin were confirmed by Western blotting (D and E). The results are presented as the mean \pm S.E. for 5-7 experimental cases in each group. * $P<0.05$. LAMP1, lysosome-associated membrane protein 1 ; KO, knockout; WT, wild type.

increased in the control diet-fed $\mathrm{KO}$ mice, and the border of the empty vacuoles was also positive for LAMP1. Highfat feeding increased the LAMP staining in wild-type mice, and clusterin deficiency further aggravated the high-fat diet-induced LAMP1 staining (Fig. 4C). Analysis of LAMP1 protein levels by Western blotting showed a similar result as that of immunohistochemistry (Fig. 4D). Megalin reabsorbs glomerular-filtered albumin and low-molecularweight proteins in proximal tubules, and these proteins are degraded by lysosomes (Christensen et al. 2012). Along with increased lysosomes, megalin protein levels were higher in clusterin $\mathrm{KO}$ mice. High-fat diet also increased megalin protein levels in wild-type mice and further increased the protein levels in clusterin KO mice (Fig. 4E). These results suggest that clusterin deficiency is associated with subcellular structural changes.

\section{Clusterin inhibits lipid accumulation in tubular epithelial cells}

To elucidate the role of clusterin in lipid metabolism in cells, lipogenic gene expression and lipid accumulation were measured in NRK52e tubular epithelial cells after modulating clusterin gene expression using siRNA and adenovirus. In control siRNA-treated cells, mRNA levels of Srebf1 and Fasn were increased by treatment with $500 \mu \mathrm{M}$ palmitate for $6 \mathrm{~h}$. Knockdown of clusterin gene expression further increased mRNA levels of Srebf1 and Fasn. Scd mRNA levels were not significantly increased by palmitate in control siRNA-treated cells, but were increased by palmitate treatment in clusterin siRNAtreated cells (Fig. 5A, B and C). Clusterin deficiency increased the palmitate-induced increase in mRNA 
A

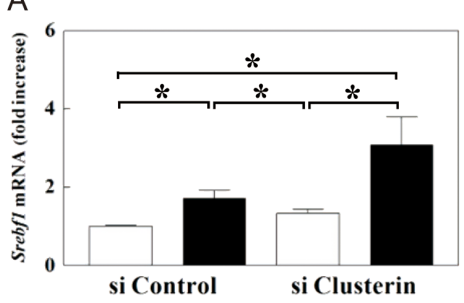

D

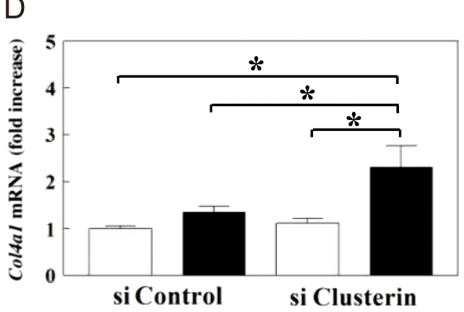

F

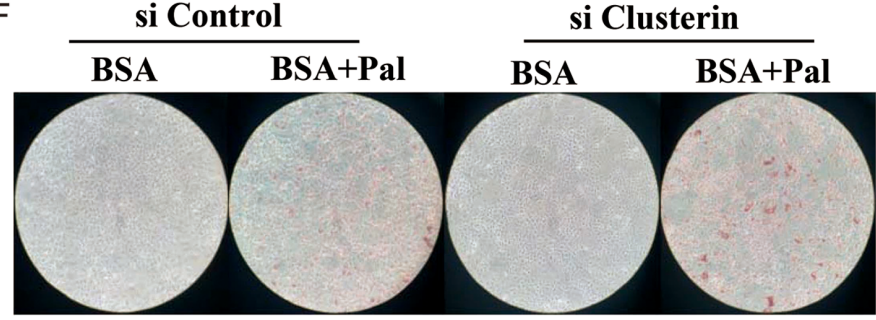

B

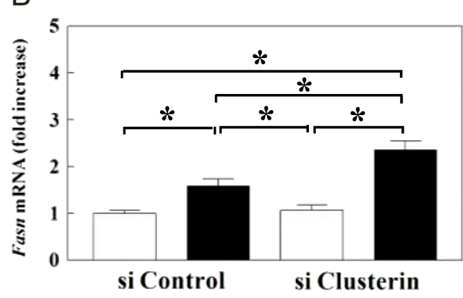

E
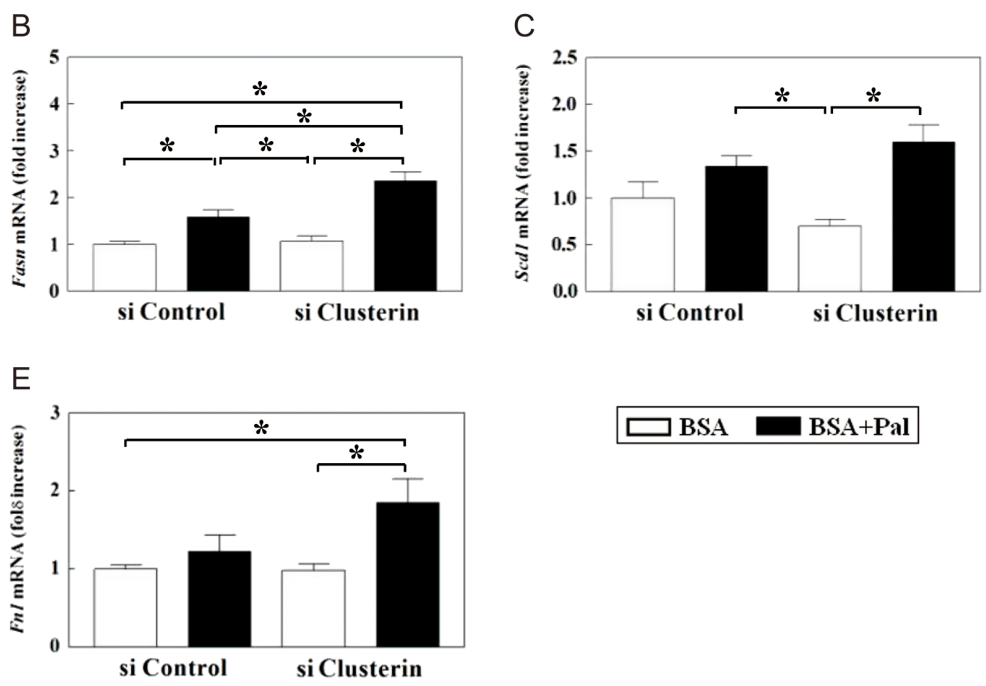

$\square$ BSA BSA+Pal

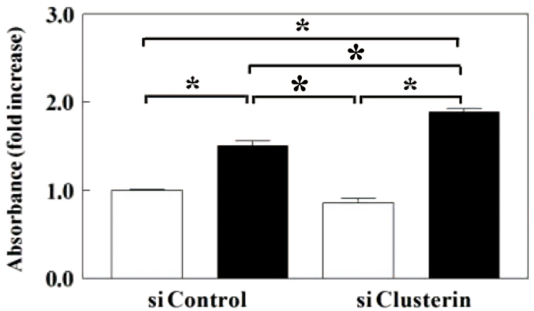

Figure 5

Gene expression of lipogenic factors and extracellular matrix-related protein and lipid levels in clusterin knockdown NRK52e cells. Clusterin knockdown was performed using small-interfering RNA (siRNA) as described in the materials and methods section. Clusterin siRNA (si clusterin) or control siRNA (si control)-transfected cells were treated with palmitate $(500 \mu \mathrm{M})$ for $6 \mathrm{~h}$ and gene expression $(\mathrm{A}, \mathrm{B}, \mathrm{C}, \mathrm{D}$ and E) was measured using qRT-PCR. Clusterin siRNA- or control siRNA-transfected cells were treated with palmitate $(250 \mu \mathrm{M})$ for $16 \mathrm{~h}$ and then Oil Red O staining was then performed. Oil Red $\mathrm{O}$ staining was visualized under a microscope $(100 x)$ and the absorbance was measured at $550 \mathrm{~nm}(\mathrm{~F})$. The results are presented as the mean \pm s.E. of $3-5$ separate experiments. ${ }^{*} P<0.05$. BSA, bovine serum albumin; Pal, palmitate.

levels of Col4a1 and Fn1 (Fig. 5D and E). Consistent with high levels of lipogenic gene expression, Oil Red O staining was also higher in cells transfected with clusterin siRNA than in those transfected with control siRNA (Fig. 5F). In contrast, overexpression of clusterin using adenovirus suppressed the mRNA expression of Srebf1, Scd and Acaca induced by $500 \mu \mathrm{M}$ palmitate for $6 \mathrm{~h}(P<0.05$ for interaction between gene and palmitate in Srebf1 and $S c d$, two-way ANOVA) (Fig. 6A, B and C). The Oil Red O staining in $250 \mu \mathrm{M}$ palmitate-treated cells for $16 \mathrm{~h}$ was also decreased by overexpression of clusterin $(P<0.05$ for interaction between gene and palmitate, two-way ANOVA) (Fig. 6D). Consistent with clusterin gene overexpression, treatment of cells with $1 \mu \mathrm{g} / \mathrm{mL}$ recombinant clusterin protein suppressed both mRNA expression of lipogenic genes and lipid accumulation $(P<0.05$ for interaction between protein and palmitate, in Fasn, Scd, Acaca and Oil Red O absorbance, two-way
ANOVA) (Fig. 6E, F, G and H). These results suggest that clusterin regulates lipogenic gene expression and lipid accumulation in tubular epithelial cells.

TGFB1 protein levels in clusterin $\mathrm{KO}$ mice were higher than those in wild-type mice. The nuclear levels of SMAD2,3 were also higher in clusterin KO mice (Fig. 7A and B). However, the plasma levels of TGFB protein were not affected by clusterin deficiency although the high-fat diet significantly increased the protein levels in mice of both genotypes (Supplementary Fig. 2). Knockdown of clusterin gene using siRNA increased the palmitate-induced $T g f b 1$ gene expression $(P<0.05$ for interaction between gene and palmitate, two-way ANOVA) (Fig. 7C). Palmitate-induced lipid accumulation in clusterin-knockdown cells was also inhibited by TGFB1 antibody treatment $(P<0.05$ for interaction between gene and antibody, two-way ANOVA) (Fig. 7D). These results suggest that TGFB1 is involved in lipid accumulation in clusterin-deficient mice. 


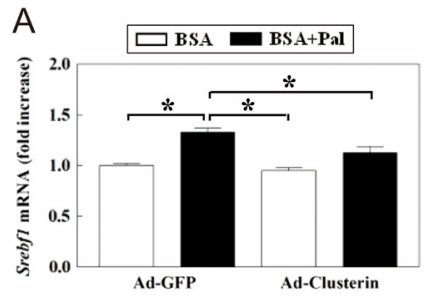

B

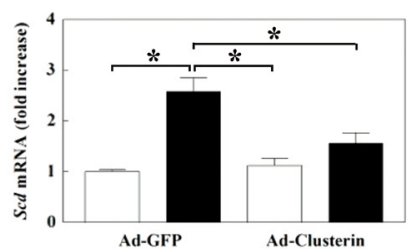

C

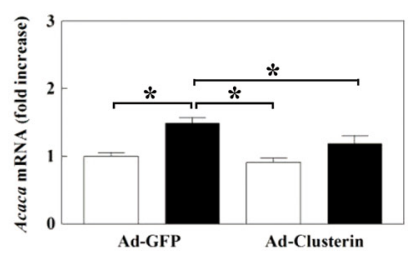

$\mathrm{D}$
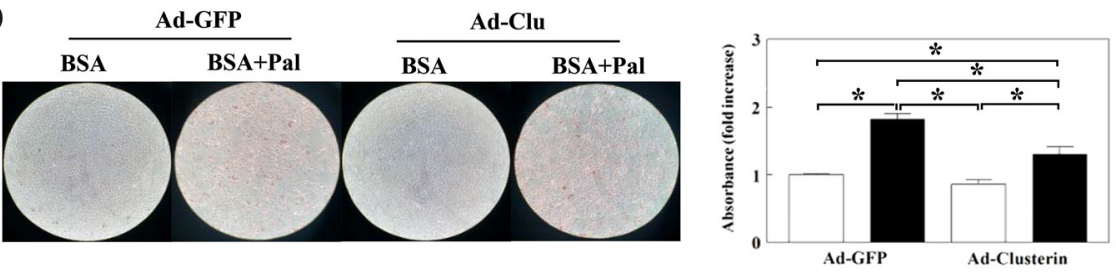

E

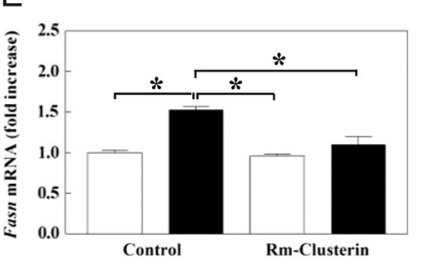

$\mathrm{F}$

G
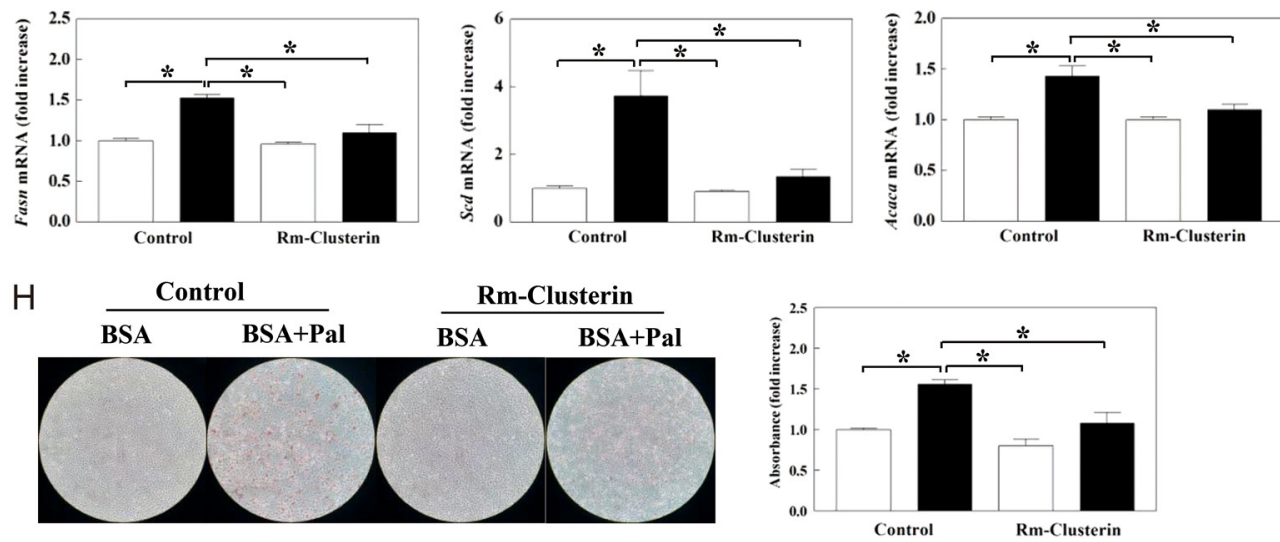

Figure 6

Gene expression of lipogenic factors and lipid levels in clusterin-overexpressing or recombinant clusterin protein-treated NRK52e cells. Clusterin was overexpressed using an adenoviral vector (Ad-Clu) as described in the 'Materials and methods' section. Cells in control group were transfected with control adenovirus expressing GFP (Ad-GFP). Gene expression was measured using qRT-PCR in cells treated with $500 \mu \mathrm{M}$ palmitate for $6 \mathrm{~h}$ (A, B and C) $(P<0.05$ for interaction between gene and palmitate in Srebf1 mRNA and Scd mRNA, two-way ANOVA). Cells were treated with palmitate ( $250 \mu \mathrm{M})$ for $16 \mathrm{~h}$, and Oil Red $\mathrm{O}$ staining was then performed. Oil Red O staining was visualized under a microscope (100x) and the absorbance was measured at $550 \mathrm{~nm}(\mathrm{D})(P<0.05$ for interaction between gene and palmitate, two-way ANOVA). Cells were treated with recombinant clusterin protein $(1 \mu \mathrm{g}) 1 \mathrm{~h}$ prior to $500 \mu \mathrm{M}$ palmitate treatment for $6 \mathrm{~h}$ and then gene expression was measured using qRT-PCR $(\mathrm{E}, \mathrm{F}$ and $\mathrm{G})(P<0.05$ for interaction between protein and palmitate, two-way ANOVA). Oil Red O staining was visualized under a microscope (100x) and the absorbance was measured at $550 \mathrm{~nm}(\mathrm{H})$ in cells treated with recombinant clusterin protein and $250 \mu \mathrm{M}$ palmitate for $16 \mathrm{~h}(P<0.05$ for interaction between clusterin protein and palmitate, two-way ANOVA). The results are presented as the mean \pm S.E. of 3-5 separate experiments. ${ }^{\star} P<0.05$. BSA, bovine serum albumin; GFP, green fluorescent protein; Rm-Clu, recombinant clusterin; Pal, palmitate.

\section{Clusterin deficiency dysregulates lipid metabolisms in mice}

To examine the role of clusterin in lipid metabolism in mice, we measured lipid uptake, triglyceride synthesis and fatty acid oxidation of clusterin $\mathrm{KO}$ and wild-type mice. Cholesterol uptake in the kidney was higher in high-fatfed clusterin KO mice compared to control diet-fed wildtype mice. Cholesterol uptake in the liver showed a similar pattern of changes with that in the kidney (Fig. 8A and B). The palmitate-induced increase in mRNA levels of $L d l r$ and Scara1 was suppressed by treatment with recombinant clusterin protein in tubular epithelial cells $(P<0.05$ for interaction between protein and palmitate, two-way ANOVA) (Fig. 8C and D). Palmitate uptake at $3 \mathrm{~h}$ was not different between the two groups in the kidney, whereas palmitate uptake in clusterin $\mathrm{KO}$ mice was significantly higher than that in wild-type mice in the liver (Fig. 8E and F). In contrast to palmitate uptake at $3 \mathrm{~h}$, palmitate uptake at $24 \mathrm{~h}$ was higher in clusterin $\mathrm{KO}$ mice than in wild-type mice (Fig. 8G). Compared to wild-type mice, triglyceride synthesis was higher in clusterin $\mathrm{KO}$ mice, whereas fatty acid oxidation was lower in clusterin $\mathrm{KO}$ mice (Fig. $8 \mathrm{H}$ and I). These results suggest that clusterin deficiency increases 
A

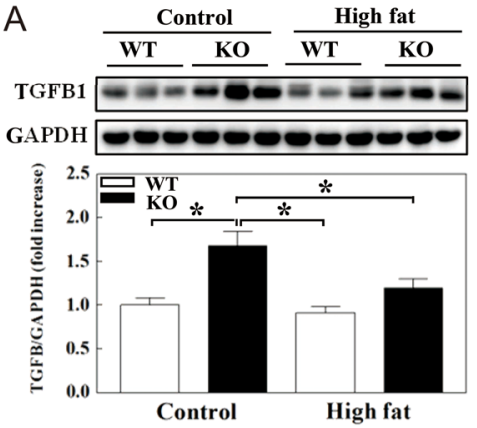

B
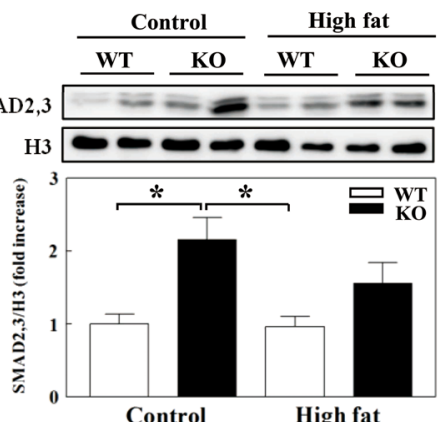

C

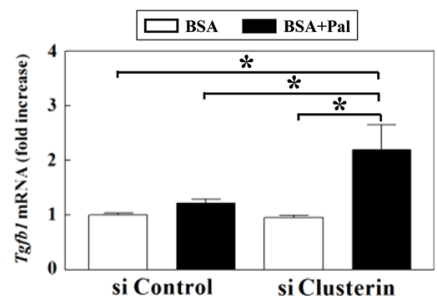

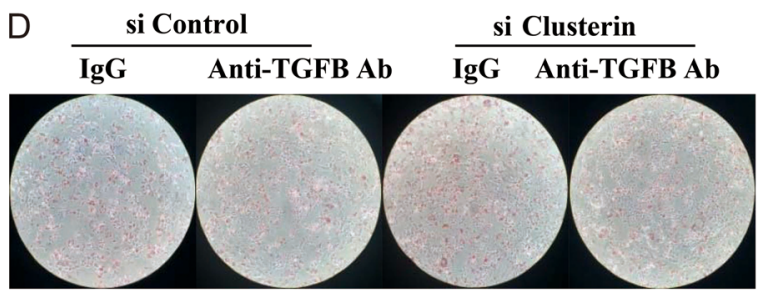

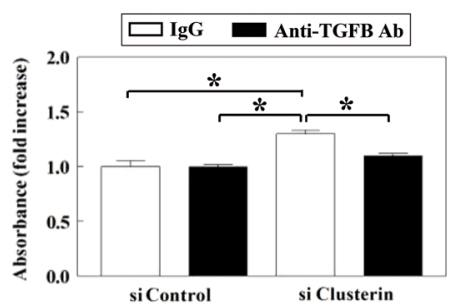

\section{Figure 7}

Effect of TGFB1 on lipid accumulation. Renal expression of TGFB1 (A) and SMAD2,3 (B) in clusterin KO and wild-type mice The results are presented as the mean \pm S.E. for $5-6$ experimental cases. NRK52e cells transfected with control siRNA (si control) and clusterin siRNA (si Clusterin) were treated with palmitate $(500 \mu \mathrm{M})$ for $6 \mathrm{~h}$, and gene expression of Tgfb1 were then measured by qRT-PCR in (C) $(P<0.05$ for interaction between gene and palmitate, two-way ANOVA). Clusterin knockdown cells were treated with TGFB1 antibody $(1 \mu \mathrm{g} / \mathrm{mL}) 1 \mathrm{~h}$ prior to $250 \mu \mathrm{M}$ palmitate treatment for $16 \mathrm{~h}$, and Oil Red $\mathrm{O}$ staining was then performed. Oil Red $\mathrm{O}$ staining was visualized under a microscope $(100 \mathrm{x})$ and the absorbance was measured at $550 \mathrm{~nm}(\mathrm{D})(P<0.05$ for interaction between gene and antibody, two-way ANOVA). Three to five separate experiments were performed in $C$ and $D$. The results are presented as the mean \pm S.E. ${ }^{*} P<0.05$. KO, knockout; TGFB1, transforming growth factor-beta1; WT, wild type.

lipid uptake and synthesis and reduces lipid utilization, leading to lipid accumulation.

\section{Discussion}

The present study demonstrates that clusterin deficiency in the kidney alters the expression of lipid metabolismrelated factors followed by increase in lipid uptake and triglyceride synthesis as well as reduction in fatty acid oxidation. The dysregulation of lipid metabolism by clusterin deficiency results in lipid accumulation and induces mesangial expansion, interstitial fibrosis and proteinuria, which are aggravated by high-fat feeding. Clusterin overexpression and treatment with recombinant clusterin protein in tubular epithelial cells suppresses the palmitate-induced lipogenic gene expression and lipid accumulation. These results suggest that clusterin protects the kidney from lipid accumulation and lipid-associated nephropathy.

Clusterin is a secretory protein that is expressed in a wide array of tissues, including the liver, skeletal muscle, adipose tissue and kidney (Dvergsten et al. 1994, Seo et al . 2013, Kwon et al. 2014, Won et al. 2014, Klouckova et al. 2016). The association between clusterin and obesity

\begin{tabular}{|lr} 
http://joe.endocrinology-journals.org & ○ 2018 Society for Endocrinology \\
https://doi.org/10.1530/JOE-17-0453 & Published by Bioscientifica Ltd. \\
Printed in Great Britain
\end{tabular}

has been previously well described in humans as well as obese experimental animals. As shown in previous studies, plasma and mRNA levels of clusterin in the subcutaneous adipose tissue are increased in human obese subjects (Won et al. 2014, Klouckova et al. 2016), and plasma and mRNA levels of clusterin in the liver and skeletal muscle are increased in high-fat-fed obese mice (Seo et al. 2013, Kwon et al. 2014). In the present study, we show that clusterin protein levels are also increased in the kidney of high-fat diet-induced obese mice. We hypothesized that increased clusterin expression suppresses lipid accumulation in the kidney of obese mice. This hypothesis is supported by a previous study showing that overexpression of clusterin prevents hepatic lipid accumulation in high-fat-fed mice (Seo et al. 2013). Consistent with our hypothesis, clusterin-deficient mice showed increased renal lipid accumulation compared to wild-type mice, as assessed by lipid extraction. We also confirmed the increase in lipid levels in clusterin $\mathrm{KO}$ mice using direct infusion-mass spectrometry analysis. Furthermore, clusterin-deficient tubular epithelial cells showed increased accumulation of lipids, whereas overexpression of clusterin or treatment with full-length clusterin protein suppressed the lipid accumulation in these cells, suggesting that clusterin prevents lipid 

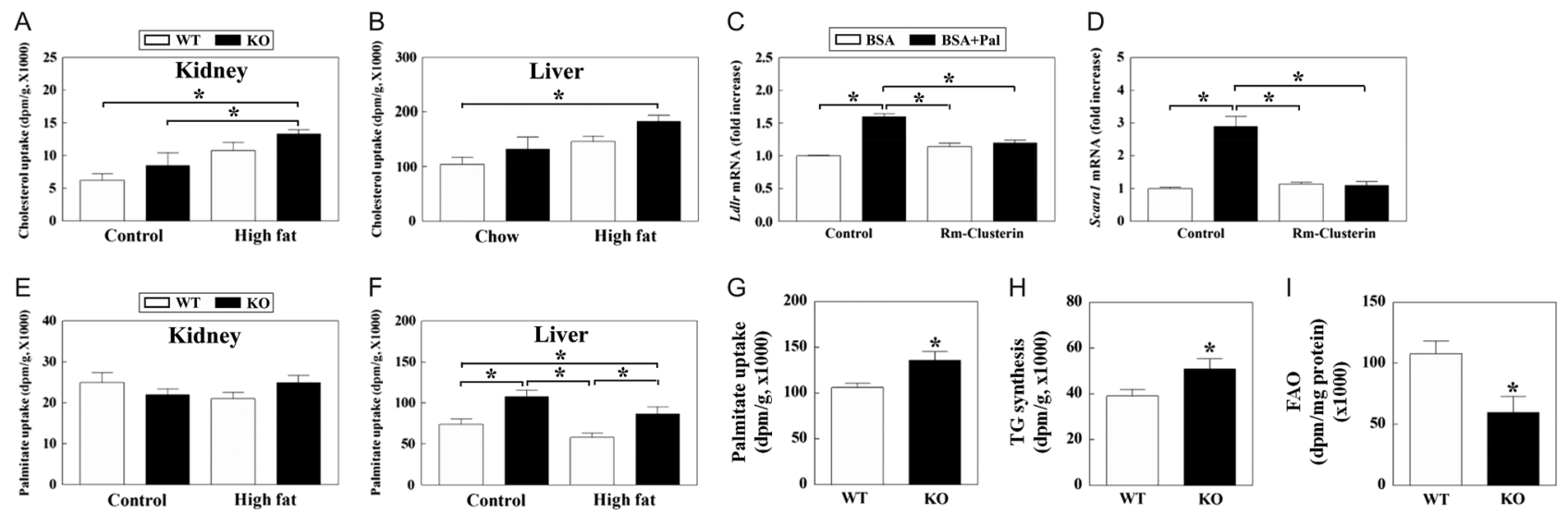

Figure 8

Functional analysis of lipid metabolism in clusterin $\mathrm{KO}$ and wild-type mice. For in vivo uptake of cholesterol, mice were administered with [3H]cholesterol by oral gavage, and the kidney (A) and liver (B) were analyzed for radioactivity at $3 \mathrm{~h}$. NRK52e cells were treated with recombinant clusterin protein $(1 \mu \mathrm{g}) 1 \mathrm{~h}$ prior to $500 \mu \mathrm{M}$ palmitate treatment for $6 \mathrm{~h}$, and gene expression was then measured using qRT-PCR $(C$ and $\mathrm{D})(P<0.05$ for interaction between protein and palmitate, two-way ANOVA). For in vivo palmitate uptake, mice were administered with $\left.{ }^{14} \mathrm{C}\right]$ palmitate by oral gavage, and the tissues were analyzed for radioactivity at $3 \mathrm{~h}\left(\mathrm{E}\right.$ and $\mathrm{F}$ ) or $24 \mathrm{~h}(\mathrm{G})$. Triglyceride synthesis was measured in the kidney of mice administered with $\left[{ }^{14} \mathrm{C}\right]$ palmitate by oral gavage $(\mathrm{H})$. Fatty acid-beta-oxidation was measured in homogenized kidney tissue using $\left[{ }^{14} \mathrm{C}\right]$ palmitate in vitro $(\mathrm{I})$. The results are presented as the mean \pm S.E. Experimental cases for mice experiments were $5-7$ in each group. Three to five separate experiments were performed for $C$ and $D$. ${ }^{*} P<0.05$. BSA, bovine serum albumin, FAO, fatty acid-beta-oxidation; KO, knockout; Pal, palmitate; Rm-Clu, recombinant clusterin; TG, triglyceride; WT, wild type.

accumulation in the kidney. However, a previous study demonstrated that clusterin deficiency does not increase lipid levels in skeletal muscle (Kwon et al. 2014), suggesting that clusterin regulates lipid metabolism in a tissue-dependent manner. A recently published study demonstrated that treatment of rabbit with beta-chain of clusterin increases body weight and lipid accumulation in the liver and kidney, but the addition of alphachain abrogates beta-chain-induced lipid accumulation, suggesting the differential role of clusterin subunits in lipid metabolism (Matukumalli et al. 2017).

Renal lipid accumulation in control diet-fed clusterin KO mice was followed by mesangial expansion and increases in protein-to-creatinine ratio, interstitial fibrosis and expression of collagen and fibronectin. These pathological changes in lean clusterin KO mice were comparable to those of high-fat diet-fed wildtype mice. Previously, clusterin KO mice have also been demonstrated to have increased gene expression of collagen1, fibronectin and plasminogen activator inhibitor1 in the kidney (Jung et al. 2012). High-fat feeding of clusterin-deficient mice showed further worsening of these changes in the kidney. In previous studies, these pathological changes were attenuated by reducing lipid accumulation, indicating that lipid accumulation is closely associated with tissue damage and functional impairment (Jiang et al. 2005b). Clusterin deficiency also causes changes in the subcellular components. It increases the number of lysosomes in the kidney tubules of control diet-fed clusterin $\mathrm{KO}$ mice, which is a characteristic feature of electron microscopic analysis in the kidney of high-fatfed obese mice (Decleves et al. 2014). Increased lysosomes in clusterin KO mice may be associated with increased megalin expression in this study. Megalin mediates accumulation of lysosomes in renal tubular epithelial cells in high-fat-fed mice and is closely associated with lysosomal dysfunction (Kuwahara et al. 2016). Moreover, megalin deficiency ameliorates high-fat diet-induced renal damage (Kuwahara et al. 2016). We assume that the elevation of protein concentration in the proximal tubules may be closely associated with enhanced megalin expression, leading to the accumulation and dysfunction of lysosome in proximal tubule cells. Mitochondrial changes following high-fat diet were aggravated in the clusterin KO mice. All the histological and structural changes observed in the present study suggest that clusterin has a protective role against lipid-induced tissue damage in the kidney of obese subjects.

In a previous study, clusterin inhibited insulininduced SREBP1c expression in a dose-dependent manner in cultured hepatocytes (Seo et al. 2013). Consistent with this, we also observed that clusterin deficiency increased SREBP1 and FAS expression in the kidney. Furthermore, overexpression of clusterin in tubular epithelial cells suppressed palmitate-induced SREBP1 expression, suggesting that clusterin also plays an important role in suppressing SREBP1 expression in the kidney. Therefore, the increased expression of SREBP1 in clusterin-deficient 


\section{Clusterin deficiency}

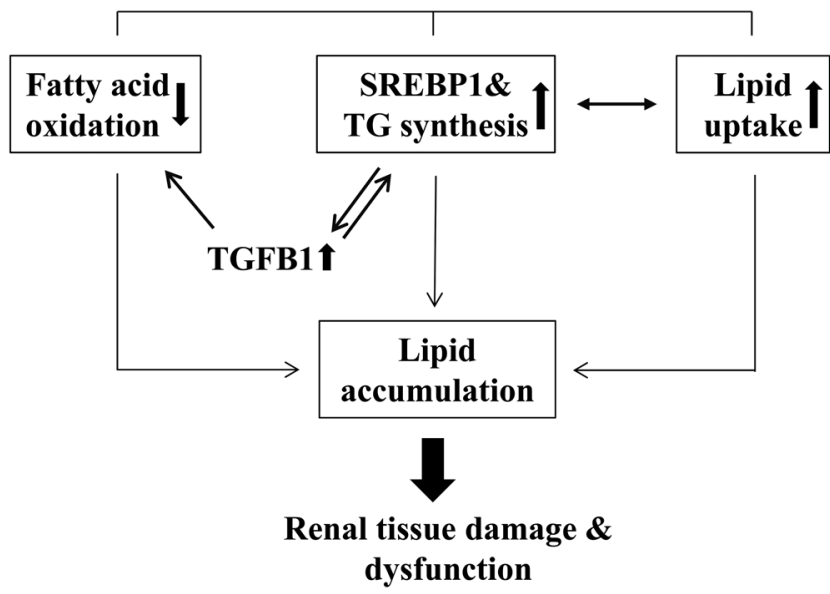

Figure 9

Schematic figure representing the effect of clusterin deficiency on renal lipid accumulation and tissue damage. Increases in triglyceride synthesis and lipid uptake, as well as reduced fatty acid oxidation result in lipid accumulation, leading to renal tissue damage and dysfunction. Increased TGFB1 levels by SREBP1 may play a role in lipid accumulation by modulating lipogenic gene expression and fatty acid oxidation. SREBP, sterol regulatory element-binding protein; TGFB1, transforming growth factor-beta1.

mice leads to lipid synthesis and accumulation. The mechanism by which clusterin deficiency induces SREBP1 expression was not investigated in the present study. It is possible that clusterin inhibits SREBP1 expression through repression of liver $X$ receptor and specificity protein 1 activity (Seo et al. 2013). Further studies are needed to clarify the underlying mechanisms. In addition to increased SREBP1 expression and triglyceride synthesis, reduced fatty acid oxidation also contributed to increased lipid accumulation in this study. Reduced protein levels of MCD are also evidence of reduced fatty acid oxidation in clusterin $\mathrm{KO}$ mice. Reduced fatty acid oxidation is accompanied by increased SREBP1 expression and lipid accumulation in the kidney of high-fat fed mice (Kume et al. 2007). No previous reports for the relationship between clusterin and fatty acid oxidation are available. In this study, TGFB1 may be related to the suppression of fatty acid oxidation in clusterin $\mathrm{KO}$ mice.

We observed that protein levels of TGFB1 and nuclear SMAD2,3 were increased in the kidney of clusterin KO mice, which has been reported in a previous study (Jung et al. 2014). Interestingly, we observed that treatment of NRK52e cells with TGFB1 antibody suppressed the palmitate-induced lipid accumulation, suggesting that TGFB1 may be involved in lipid accumulation in clusterindeficient mice. Consistent with this result, increased lipid accumulation by TGFB signaling has been previously reported in hepatocytes (Yang et al. 2014). However, it is unclear in this study whether clusterin deficiency directly increases TGFB1 expression. Previously, the regulatory effect of SREBP1 on TGFB1 has been reported; overexpression of SREBP1a or SREBP1c in the kidney enhances TGFB1 expression, and high glucose activation of SREBP1 mediates upregulation of TGFB1 (Sun et al. 2002, Ishigaki et al. 2007, Uttarwar et al. 2012). TGFB induces hepatic lipogenesis through increased expression of Dgat1, Fasn and Srebf1 as well as reduced expression of Cpt1 and Acox1 (Yang et al. 2014). Moreover, TGFB1 directly suppresses fatty acid oxidation in tubular epithelial cells (Kang et al. 2015). In our study, TGFB may contribute to increased lipid accumulation by increasing lipogenic gene expression and reducing fatty acid oxidation.

Interestingly, palmitate uptake was increased $24 \mathrm{~h}$ after oral administration of $\left[{ }^{14} \mathrm{C}\right]$ palmitate but not at $3 \mathrm{~h}$ in the kidney. Delayed uptake of fatty acids has been observed in a previous study, in which adipose tissue uptake of $\left[{ }^{14} \mathrm{C}\right]$ oleic acid is similar to that of wild-type mice at $2 \mathrm{~h}$ but increases at $24 \mathrm{~h}$ in vascular endothelial growth factor B KO mice (Hagberg et al. 2010). The mechanism of increased palmitate uptake at $24 \mathrm{~h}$ in this study is unclear as the levels of fatty acid transporters were unaltered by clusterin deficiency. However, it is possible that increased megalin may mediate palmitate uptake through increased reabsorption of albumin and fatty acid-binding protein 1 (Oyama et al. 2005, Christensen et al. 2012,). Increased filtration of fatty acid-bound albumin causes fatty acid accumulation and lipotoxicity in the proximal tubule (Bobulescu 2010). Moreover, it has previously been reported that uptake of fatty acid-bound albumin via megalin induces giant lysosomal formation in tubular epithelial cells (Kuwahara et al. 2016), which suggests that megalin-mediated fatty acid uptake is not only involved in increased lipid accumulation but also in the lysosomal dysfunction in the kidney.

Additionally, clusterin might prevent lipid accumulation by inhibiting cholesterol uptake, which is supported by increased cholesterol uptake and cholesterol levels in the kidney of clusterin-deficient mice. Increased gene expression of LDLR by palmitate was suppressed by treatment with recombinant clusterin protein, thereby supporting our notion. SREBP1 is known to regulate cholesterol uptake by regulating the expression of LDLR (Streicher et al. 1996). We assume that increased SREBP1 by clusterin deficiency elevates LDLR expression levels, leading to increased cholesterol uptake. However, the expression of scavenger receptor class A1 (SR-A1), involved in the uptake of oxidized LDL, was also increased 
in clusterin-deficient mice, indicating that other factors may also be involved in cholesterol uptake as there is no evidence that SR-A1 gene expression is regulated by SREBP1.

Due to whole-body KO of clusterin in this study, clusterin deficiency in extra-renal tissue may affect pathological phenomena in the kidney. Clusterin has a protective role against hepatic lipid accumulation and cardiac inflammation, and clusterin deficiency in these tissues may partly contribute to the aggravation of renal tissue damage (Seo et al. 2013, Pereira et al. 2018). Increased insulin levels in high-fat-fed clusterin $\mathrm{KO}$ mice (Kwon et al. 2014) may also affect the regulation of SREBP1 expression in the kidney.

Based on our results, we suggest that clusterin deficiency increases lipid accumulation by dysregulating lipid metabolism and TGFB1 expression in the kidney, leading to tissue damage and reduced renal function (Fig. 9). In conclusion, clusterin prevents lipid accumulation in the kidney, and hence, may serve as a therapeutic target for obesity-induced chronic kidney disease.

\section{Supplementary data}

This is linked to the online version of the paper at https://doi.org/10.1530/ JOE-17-0453.

\section{Declaration of interest}

The authors declare that there is no conflict of interest that could be perceived as prejudicing the impartiality of the research reported.

\section{Funding}

This work was supported by the Medical Research Center Program (2015R1A5A2009124) and the Basic Science Research Program (2013R1A1A2009257) of the National Research Foundation of Korea (NRF) funded by the Ministry of Science, ICT and Future Planning.

\section{References}

Bobulescu IA 2010 Renal lipid metabolism and lipotoxicity. Current Opinion in Nephrology and Hypertension 19 393-402. (https://doi org/10.1097/MNH.0b013e32833aa4ac)

Christensen EI, Birn H, Storm T, Weyer K \& Nielsen R 2012 Endocytic receptors in the renal proximal tubule. Physiology 27 223-236.

Decleves AE, Zolkipli Z, Satriano J, Wang L, Nakayama T, Rogac M, Le TP, Nortier JL, Farquhar MG, Naviaux RK, et al. 2014 Regulation of lipid accumulation by AMP-activated kinase [corrected] in high fat dietinduced kidney injury. Kidney International 85 611-623. (https://doi. org/10.1038/ki.2013.462)

Dvergsten J, Manivel JC, Correa-Rotter R \& Rosenberg ME 1994 Expression of clusterin in human renal diseases. Kidney International 45 828-835. (https://doi.org/10.1038/ki.1994.109)
Eberle D, Hegarty B, Bossard P, Ferre P \& Foufelle F 2004 SREBP transcription factors: master regulators of lipid homeostasis. Biochimie 86 839-848. (https://doi.org/10.1016/j.biochi.2004.09.018)

Gil SY, Youn BS, Byun K, Huang H, Namkoong C, Jang PG, Lee JY, Jo YH, Kang GM, Kim HK, et al. 2013 Clusterin and LRP2 are critical components of the hypothalamic feeding regulatory pathway. Nature Communications 4 1862. (https://doi.org/10.1038/ncomms2896)

Gosmain Y, Dif N, Berbe V, Loizon E, Rieusset J, Vidal H \& Lefai E 2005 Regulation of SREBP-1 expression and transcriptional action on HKII and FAS genes during fasting and refeeding in rat tissues. Journal of Lipid Research 46 697-705. (https://doi.org/10.1194/jlr.M400261JLR200)

Hagberg CE, Falkevall A, Wang X, Larsson E, Huusko J, Nilsson I, van Meeteren LA, Samen E, Lu L, Vanwildemeersch M, et al. 2010 Vascular endothelial growth factor B controls endothelial fatty acid uptake. Nature 464 917-921. (https://doi.org/10.1038/nature08945)

Hamada N, Miyata M, Eto H, Ikeda Y, Shirasawa T, Akasaki Y, Miyauchi T, Furusho Y, Nagaki A, Aronow BJ, et al. 2011 Loss of clusterin limits atherosclerosis in apolipoprotein E-deficient mice via reduced expression of Egr-1 and TNF-alpha. Journal of Atherosclerosis and Thrombosis 18 209-216. (https://doi.org/10.5551/jat.5819)

Hamilton JG \& Comai K 1988 Rapid separation of neutral lipids, free fatty acids and polar lipids using prepacked silica Sep-Pak columns. Lipids 23 1146-1149. (https://doi.org/10.1007/BF02535281)

Hua X, Wu J, Goldstein JL, Brown MS \& Hobbs HH 1995 Structure of the human gene encoding sterol regulatory element binding protein-1 (SREBF1) and localization of SREBF1 and SREBF2 to chromosomes 17p11.2 and 22q13. Genomics 25 667-673. (https://doi. org/10.1016/0888-7543(95)80009-B)

Ishigaki N, Yamamoto T, Shimizu Y, Kobayashi K, Yatoh S, Sone H, Takahashi A, Suzuki H, Yamagata K, Yamada N, et al. 2007 Involvement of glomerular SREBP-1c in diabetic nephropathy. Biochemical and Biophysical Research Communications 364 502-508. (https://doi.org/10.1016/j.bbrc.2007.10.038)

Jenne DE, Lowin B, Peitsch MC, Bottcher A, Schmitz G \& Tschopp J 1991 Clusterin (complement lysis inhibitor) forms a high density lipoprotein complex with apolipoprotein A-I in human plasma. Journal of Biological Chemistry 266 11030-11036.

Jiang T, Liebman SE, Lucia MS, Li J \& Levi M 2005a Role of altered renal lipid metabolism and the sterol regulatory element binding proteins in the pathogenesis of age-related renal disease. Kidney International 68 2608-2620. (https://doi.org/10.1111/j.15231755.2005.00733.x)

Jiang T, Wang Z, Proctor G, Moskowitz S, Liebman SE, Rogers T, Lucia MS, Li J \& Levi M 2005b Diet-induced obesity in C57BL/6J mice causes increased renal lipid accumulation and glomerulosclerosis via a sterol regulatory element-binding protein-1c-dependent pathway. Journal of Biological Chemistry 280 32317-32325. (https://doi.org/10.1074/jbc. M500801200)

Jung GS, Kim MK, Jung YA, Kim HS, Park IS, Min BH, Lee KU, Kim JG, Park KG \& Lee IK 2012 Clusterin attenuates the development of renal fibrosis. Journal of the American Society of Nephrology 23 73-85. (https:// doi.org/10.1681/ASN.2011010048)

Jung GS, Jeon JH, Jung YA, Choi YK, Kim HS, Kim JG, Park KG, Kim MK \& Lee IK 2014 Clusterin/apolipoprotein J attenuates angiotensin II-induced renal fibrosis. PLOS ONE 9 e105635. (https://doi. org/10.1371/journal.pone.0105635)

Kambham N, Markowitz GS, Valeri AM, Lin J \& D'Agati VD 2001 Obesity-related glomerulopathy: an emerging epidemic. Kidney International 59 1498-1509. (https://doi.org/10.1046/j.15231755.2001.0590041498.x)

Kang HM, Ahn SH, Choi P, Ko YA, Han SH, Chinga F, Park AS, Tao J, Sharma K, Pullman J, et al. 2015 Defective fatty acid oxidation in renal tubular epithelial cells has a key role in kidney fibrosis development. Nature Medicine 21 37-46. (https://doi.org/10.1038/ $\mathrm{nm} .3762$ ) 
Kim JY, Hickner RC, Cortright RL, Dohm GL \& Houmard JA 2000 Lipid oxidation is reduced in obese human skeletal muscle. American Journal of Physiology: Endocrinology and Metabolism 279 E1039-E1044. (https:// doi.org/10.1152/ajpendo.2000.279.5.E1039)

Kim SJ, Kim JE, Kim YW, Kim JY \& Park SY 2017 Nutritional regulation of renal lipogenic factor expression in mice: comparison to regulation in the liver and skeletal muscle. American Journal of Physiology: Renal Physiology 0059402016.

Kind T, Liu KH, Lee DY, DeFelice B, Meissen JK \& Fiehn O 2013 LipidBlast in silico tandem mass spectrometry database for lipid identification. Nature Methods 10 755-758. (https://doi.org/10.1038/nmeth.2551)

Kiortsis DN \& Christou MA 2012 Management of obesity-induced kidney disease: a critical review of the literature. Obesity Facts 5 821-832. (https://doi.org/10.1159/000345919)

Klouckova J, Lacinova Z, Kavalkova P, Trachta P, Kasalicky M, Haluzikova D, Mraz M \& Haluzik M 2016 Plasma concentrations and subcutaneous adipose tissue mRNA expression of clusterin in obesity and type 2 diabetes mellitus: the effect of short-term hyperinsulinemia, very-low-calorie diet and bariatric surgery. Physiological Research 65 481-492.

Kume S, Uzu T, Araki S, Sugimoto T, Isshiki K, Chin-Kanasaki M, Sakaguchi M, Kubota N, Terauchi Y, Kadowaki T, et al. 2007 Role of altered renal lipid metabolism in the development of renal injury induced by a high-fat diet. Journal of the American Society of Nephrology 18 2715-2723. (https://doi.org/10.1681/ASN.2007010089)

Kuwahara S, Hosojima M, Kaneko R, Aoki H, Nakano D, Sasagawa T, Kabasawa H, Kaseda R, Yasukawa R, Ishikawa T,et al. 2016 Megalinmediated tubuloglomerular alterations in high-fat diet-induced kidney disease. Journal of the American Society of Nephrology $\mathbf{2 7}$ 1996-2008. (https://doi.org/10.1681/ASN.2015020190)

Kwon MJ, Ju TJ, Heo JY, Kim YW, Kim JY, Won KC, Kim JR, Bae YK, Park IS, Min BH, et al. 2014 Deficiency of clusterin exacerbates highfat diet-induced insulin resistance in male mice. Endocrinology $\mathbf{1 5 5}$ 2089-2101. (https://doi.org/10.1210/en.2013-1870)

Laville M 2011 Renal consequences of obesity. Nephrology and Therapeutics 7 80-85. (https://doi.org/10.1016/j.nephro.2010.11.007)

Lloyd AC, Carpenter CA \& Saggerson ED 1986 Intertissue differences in the hysteretic behaviour of carnitine palmitoyltransferase in the presence of malonyl-CoA. Biochemical Journal 237 289-291. (https:// doi.org/10.1042/bj2370289)

Masson P, Alves AC, Ebbels TM, Nicholson JK \& Want EJ 2010 Optimization and evaluation of metabolite extraction protocols for untargeted metabolic profiling of liver samples by UPLC-MS Analytical Chemistry 82 7779-7786. (https://doi.org/1021/ac101722e)

Matukumalli SR, Tangirala R \& Rao CM 2017 Clusterin: full-length protein and one of its chains show opposing effects on cellular lipid accumulation. Scientific Reports 7 41235. (https://doi.org/10.1038/ srep41235)

Mokdad AH, Ford ES, Bowman BA, Dietz WH, Vinicor F, Bales VS \& Marks JS 2003 Prevalence of obesity, diabetes, and obesity-related health risk factors, 2001. JAMA 289 76-79.

Moll S, Menoud PA, French L, Sappino AP, Pastore Y, Schifferli JA \& Izui S 1998 Tubular up-regulation of clusterin mRNA in murine lupus-like nephritis. American Journal of Pathology 152 953-962.

Mount P, Davies M, Choy SW, Cook N \& Power D 2015 Obesity-related chronic kidney disease-the role of lipid metabolism. Metabolites $\mathbf{5}$ 720-732. (https://doi.org/10.3390/metabo5040720)

Nohturfft A, DeBose-Boyd RA, Scheek S, Goldstein JL \& Brown MS 1999 Sterols regulate cycling of SREBP cleavage-activating protein (SCAP) between endoplasmic reticulum and Golgi. PNAS 96 11235-11240. (https://doi.org/10.1073/pnas.96.20.11235)

Odagiri K, Mizuta I, Yamamoto M, Miyazaki Y, Watanabe H \& Uehara A 2014 Waist to height ratio is an independent predictor for the incidence of chronic kidney disease. PLOS ONE 9 e88873. (https://doi. org/10.1371/journal.pone.0088873)
Oh SY, Park SK, Kim JW, Ahn YH, Park SW \& Kim KS 2003 Acetyl-CoA carboxylase beta gene is regulated by sterol regulatory elementbinding protein-1 in liver. Journal of Biological Chemistry $\mathbf{2 7 8}$ 28410-28417. (https://doi.org/10.1074/jbc.M300553200)

Oyama Y, Takeda T, Hama H, Tanuma A, Iino N, Sato K, Kaseda R, Ma M, Yamamoto T, Fujii H, et al. 2005 Evidence for megalinmediated proximal tubular uptake of L-FABP, a carrier of potentially nephrotoxic molecules. Laboratory Investigation 85 522-531. (https:// doi.org/10.1038/labinvest.3700240)

Pereira RM, Mekary RA, da Cruz Rodrigues KC, Anaruma CP, Ropelle ER, da Silva ASR, Cintra DE, Pauli JR \& de Moura LP 2018 Protective molecular mechanisms of clusterin against apoptosis in cardiomyocytes. Heart Failure Reviews 23 123-129. (https://doi. org/10.1007/s10741-017-9654-z)

Pettinelli P, Del Pozo T, Araya J, Rodrigo R, Araya AV, Smok G, Csendes A, Gutierrez L, Rojas J, Korn O, et al. 2009 Enhancement in liver SREBP-1c/PPAR-alpha ratio and steatosis in obese patients: correlations with insulin resistance and n-3 long-chain polyunsaturated fatty acid depletion. Biochimica et Biophysica Acta 1792 1080-1086. (https://doi.org/10.1016/j.bbadis.2009.08.015)

Rosenberg ME \& Silkensen J 1995 Clusterin: physiologic and pathophysiologic considerations. International Journal of Biochemistry and Cell Biology 27 633-645. (https://doi.org/10.1016/13572725(95)00027-M)

Rosenberg ME, Girton R, Finkel D, Chmielewski D, Barrie A 3rd, Witte DP, Zhu G, Bissler JJ, Harmony JA \& Aronow BJ 2002 Apolipoprotein J/ clusterin prevents a progressive glomerulopathy of aging. Molecular and Cellular Biology 22 1893-1902. (https://doi.org/10.1128/ MCB.22.6.1893-1902.2002)

Seo HY, Kim MK, Jung YA, Jang BK, Yoo EK, Park KG \& Lee IK 2013 Clusterin decreases hepatic SREBP-1c expression and lipid accumulation. Endocrinology 154 1722-1730. (https://doi. org/10.1210/en.2012-2009)

Shimano H, Shimomura I, Hammer RE, Herz J, Goldstein JL, Brown MS \& Horton JD 1997 Elevated levels of SREBP-2 and cholesterol synthesis in livers of mice homozygous for a targeted disruption of the SREBP-1 gene. Journal of Clinical Investigation 100 2115-2124. (https://doi. org/10.1172/JCI119746)

Shon JC, Shin HS, Seo YK, Yoon YR, Shin H Liu KH 2015 Direct infusion MS-based lipid profiling reveals the pharmacological effects of compound K-reinforced ginsenosides in high-fat diet induced obese mice. Journal of Agricultural and Food Chemistry 63 2919-2929. (https://doi.org/10.1021/jf506216p)

Stanley WC, Morgan EE, Huang H, McElfresh TA, Sterk JP, Okere IC, Chandler MP, Cheng J, Dyck JR \& Lopaschuk GD 2005 Malonyl-CoA decarboxylase inhibition suppresses fatty acid oxidation and reduces lactate production during demand-induced ischemia. American Journal of Physiology: Heart and Circulatory Physiology 289 H2304-H2309. (https://doi.org/10.1152/ajpheart.00599.2005)

Streicher R, Kotzka J, Muller-Wieland D, Siemeister G, Munck M, Avci H \& Krone W 1996 SREBP-1 mediates activation of the low density lipoprotein receptor promoter by insulin and insulin-like growth factor-I. Journal of Biological Chemistry 271 7128-7133. (https://doi org/10.1074/jbc.271.12.7128)

Sun L, Halaihel N, Zhang W, Rogers T \& Levi M 2002 Role of sterol regulatory element-binding protein 1 in regulation of renal lipid metabolism and glomerulosclerosis in diabetes mellitus. Journal of Biological Chemistry 277 18919-18927. (https://doi.org/10.1074/jbc. M110650200)

Szeto HH, Liu S, Soong Y, Alam N, Prusky GT \& Seshan SV 2016 Protection of mitochondria prevents high-fat diet-induced glomerulopathy and proximal tubular injury. Kidney International 90 997-1011. (https://doi.org/10.1016/j.kint.2016.06.013)

Uttarwar L, Gao B, Ingram AJ \& Krepinsky JC 2012 SREBP-1 activation by glucose mediates TGF-beta upregulation in mesangial cells. American http://joe.endocrinology-journals.org

https://doi.org/10.1530/JOE-17-0453 (c) 2018 Society for Endocrinology Published by Bioscientifica Ltd. Printed in Great Britain 
Journal of Physiology: Renal Physiology 302 F329-F341. (https://doi. org/10.1152/ajprenal.00136.2011)

Wahba IM \& Mak RH 2007 Obesity and obesity-initiated metabolic syndrome: mechanistic links to chronic kidney disease. Clinical Journal of the American Society of Nephrology 2 550-562. (https://doi. org/10.2215/CJN.04071206)

Won JC, Park CY, Oh SW, Lee ES, Youn BS \& Kim MS 2014 Plasma clusterin (ApoJ) levels are associated with adiposity and systemic inflammation. PLOS ONE 9 e103351. (https://doi.org/10.1371/journal.pone.0103351)

Wu Z, Shon JC, Kim JY, Cho Y \& Liu KH 2016 Structural identification of skin ceramides containing $\omega$-hydroxy acyl chains using mass spectrometry. Archives of Pharmacal Research 39 1426-1432. (https:// doi.org/10.1007/s12272-016-0794-9)

Yang L, Roh YS, Song J, Zhang B, Liu C, Loomba R \& Seki E 2014 Transforming growth factor beta signaling in hepatocytes participates in steatohepatitis through regulation of cell death and lipid metabolism in mice. Hepatology 59 483-495. (https://doi.org/10.1002/ hep.26698)

Zhou W, Guan Q, Kwan CC, Chen H, Gleave ME, Nguan CY \& Du C 2010 Loss of clusterin expression worsens renal ischemia-reperfusion injury. American Journal of Physiology: Renal Physiology 298 F568-F578. (https://doi.org/10.1152/ajprenal.00399.2009)

Received in final form 8 March 2018

Accepted 21 March 2018

Accepted Preprint published online 21 March 2018
(C) 2018 Society for Endocrinology Published by Bioscientifica Ltd. 